\title{
IrT- 199
}

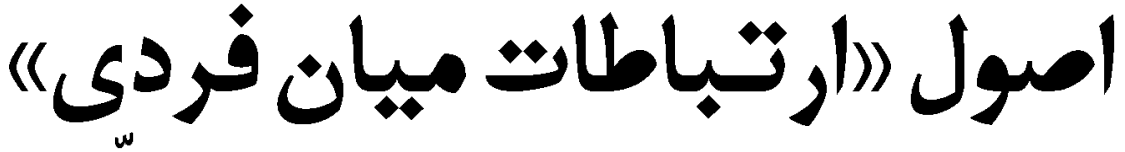 بر اساس ديدكاه علامه حلى إنى

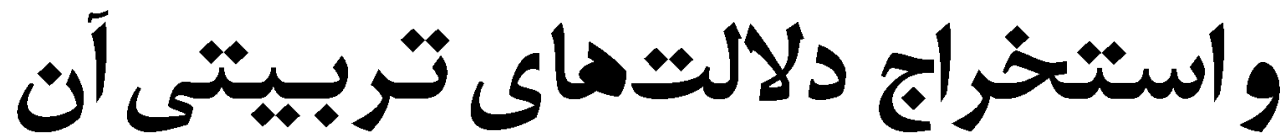

* فاطمه وجدانى

\section{Oئم}

كسب مهارتهاي ارتباطى ميانفردى موثر ، به كونهاي كه هم رشد و سعادت فردى و هم اهم اهداف

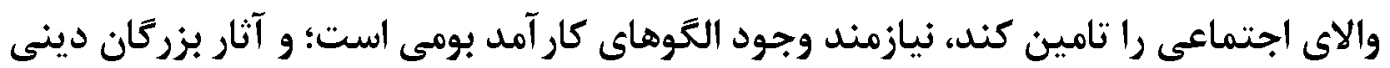

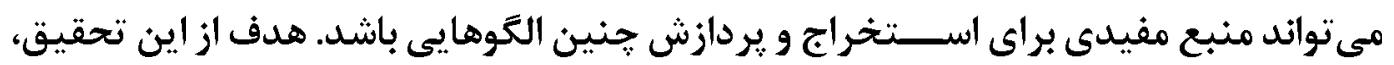

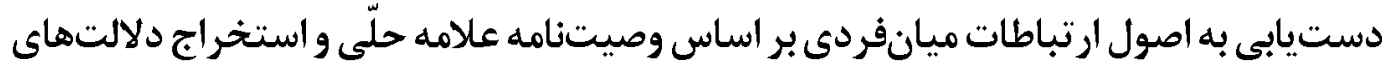

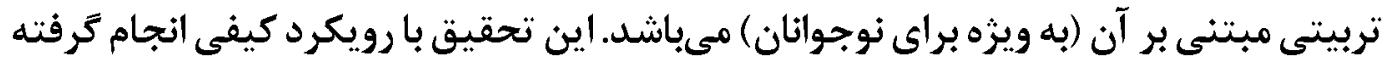

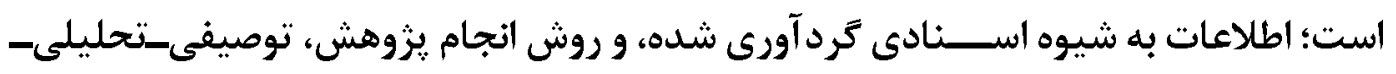

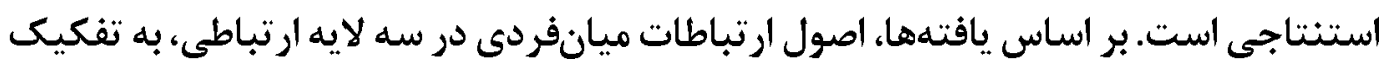

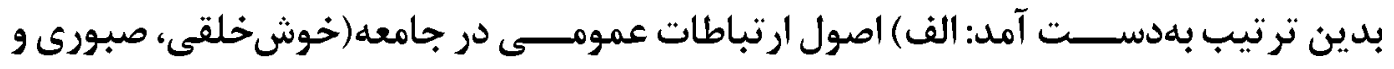

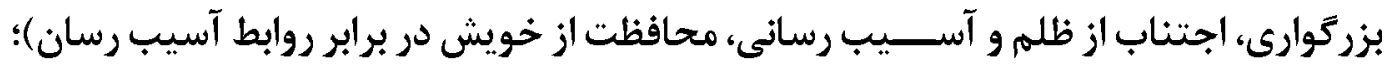

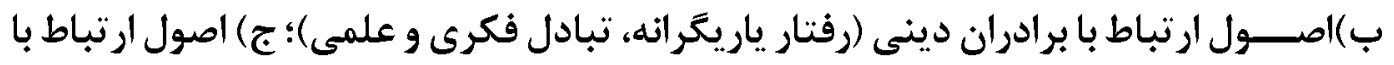

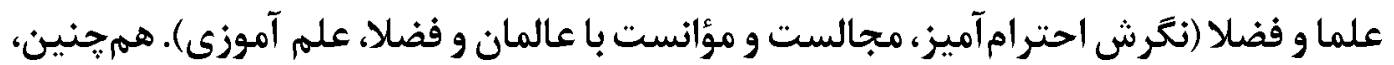

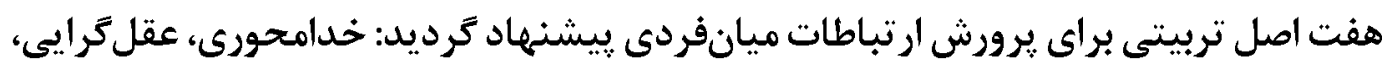

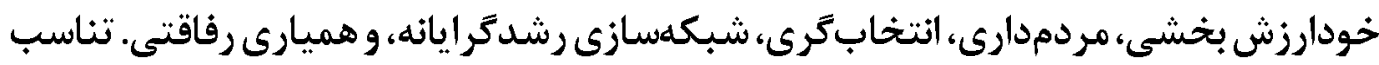

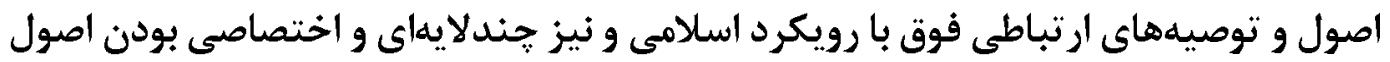
ارتباطى را مى توان از جمله نقاط قوت ديدكاه فياه علامه حلّى دانست.

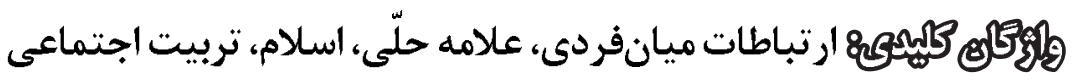




\section{مقدمه - مقا}

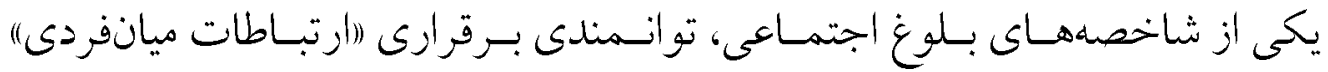

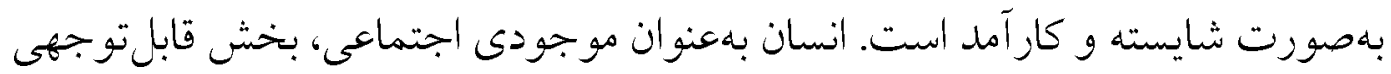

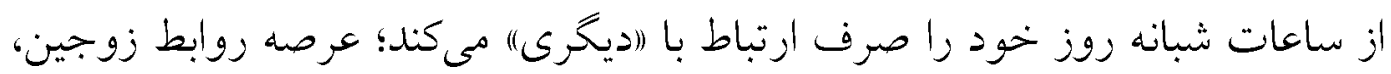

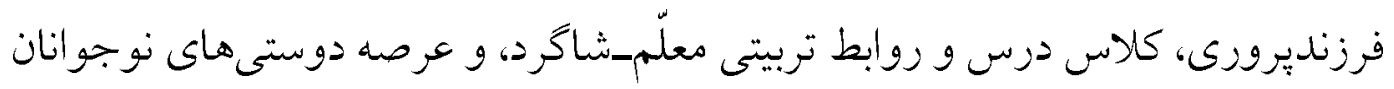

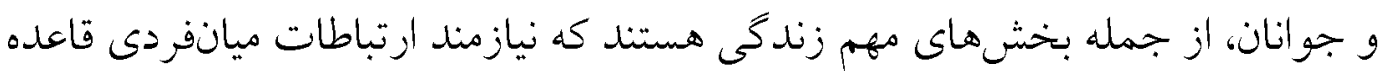

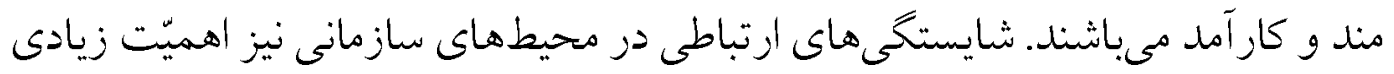

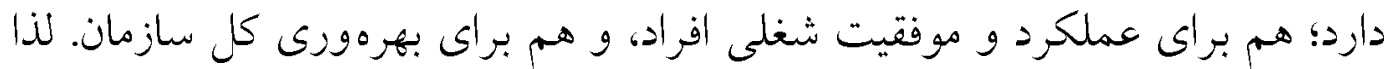

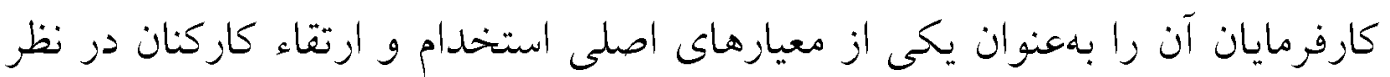

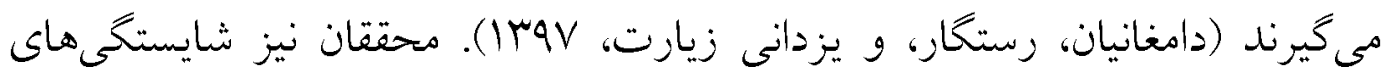

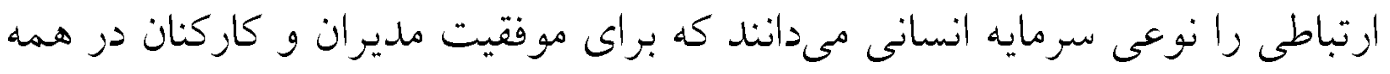

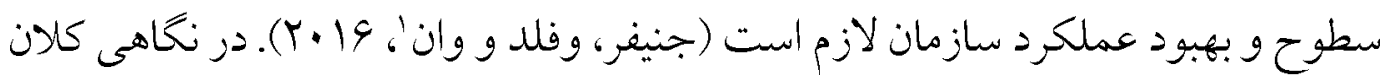

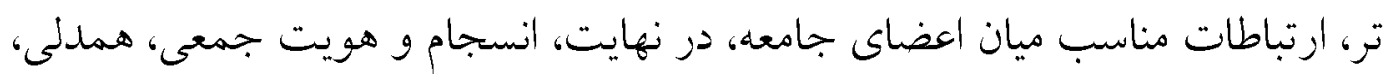
محبت و تعاون را در جامعه ارتقاء مىبخشد.

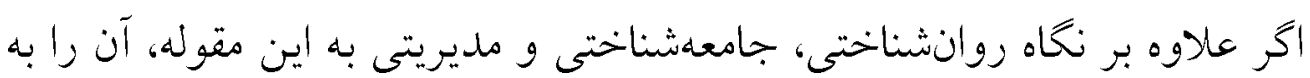

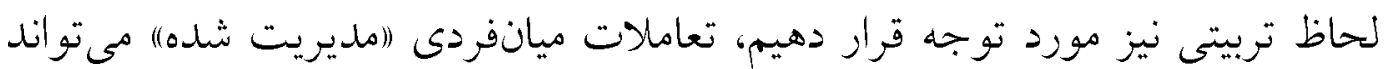

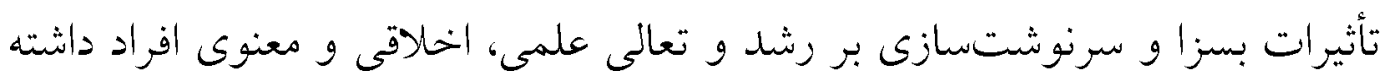

"ارتباط ميانفردى") فرايندى است كه به وسيله آن اطلاعات، معانى و احساسات

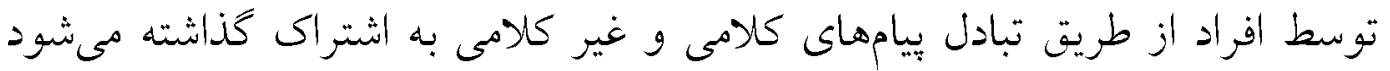

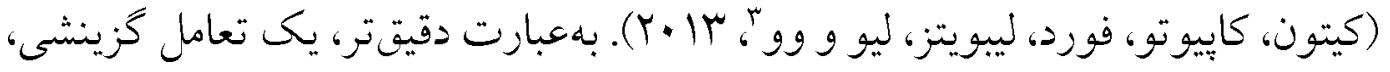

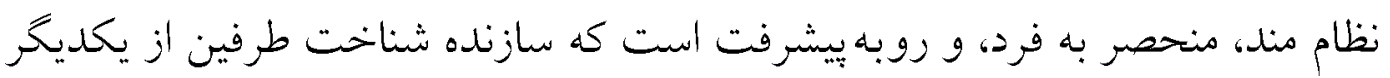

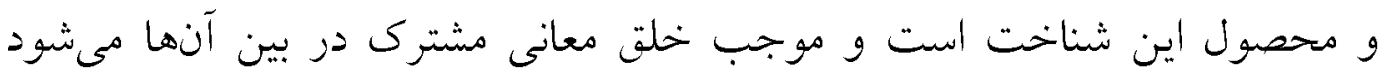

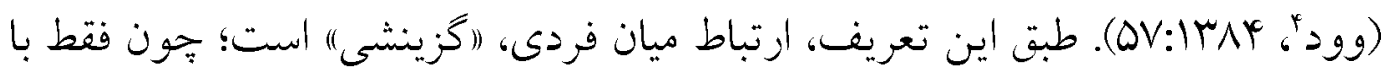

1. Jennifer, Wefald \& Van

2. Interpersonal Communication interpersonal communication

3. Keyton, Caputo, Ford, Leibowitz, Liu \& Wu

4. wood 
الصول (أرتباطات ميان فردى)، بر اسياس

ديكاه علاهـ حلى و استخراج دلالت هائ ترييتى آن

TrT-149

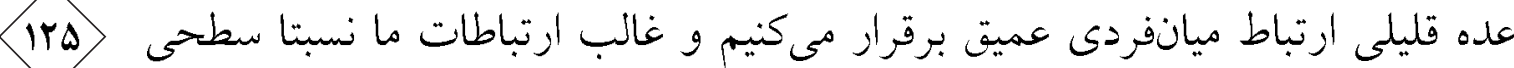

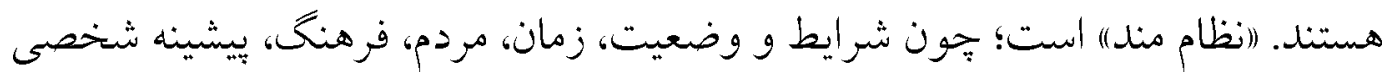

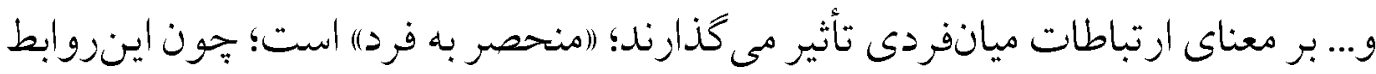
فراتر از نقشهاى اجتماعى است و افر اد بى بلديل هستند؛ و اين فرايند لاروبه يِيشرفت و

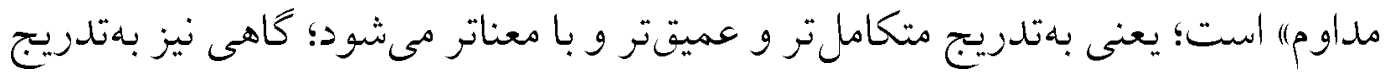

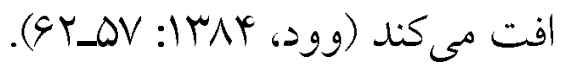

فقدان مهارت در اين امر مهم مىتواند به خود فرد، مخاطب ارتباط و كال جامعده

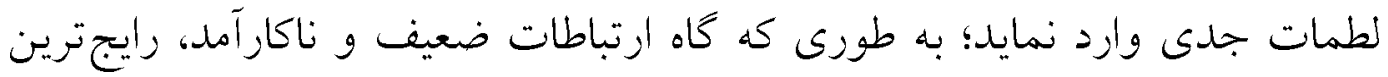

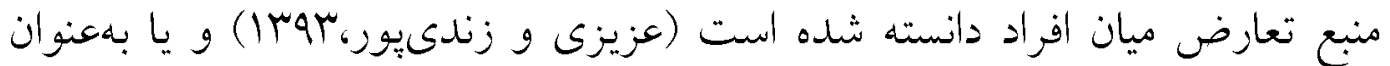

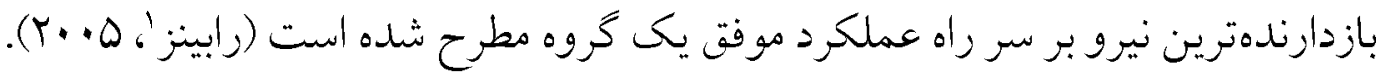

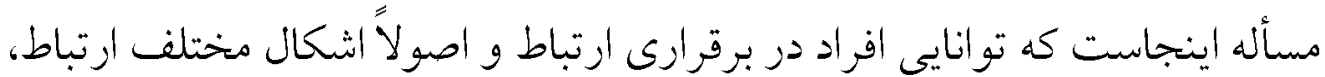

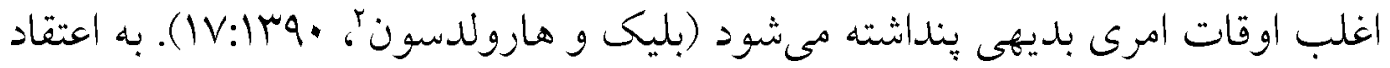

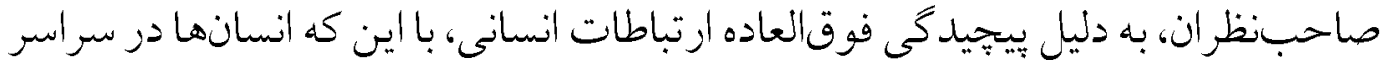

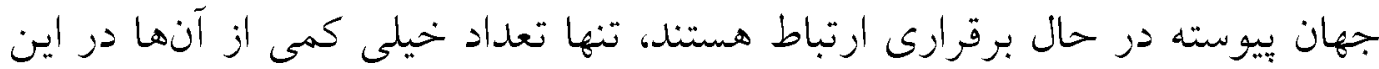

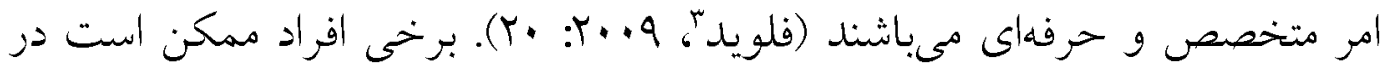

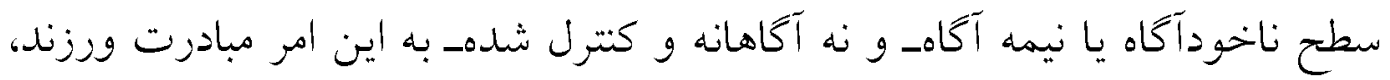

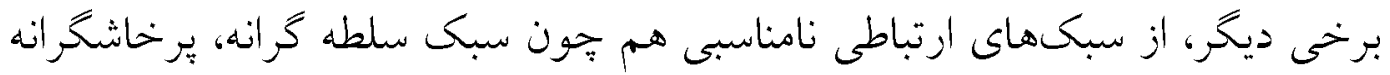

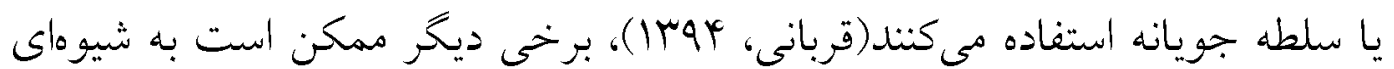

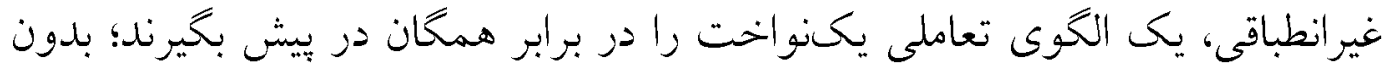

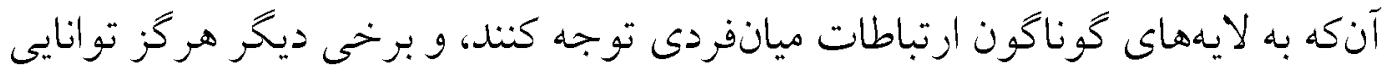

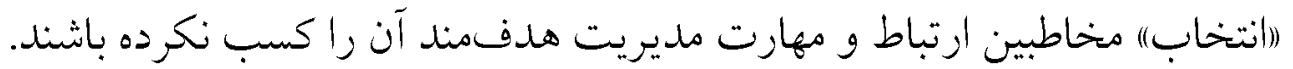

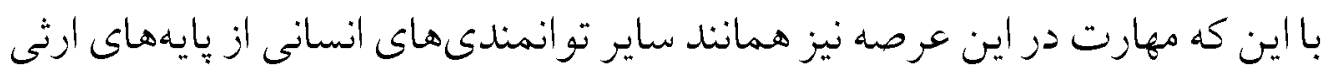

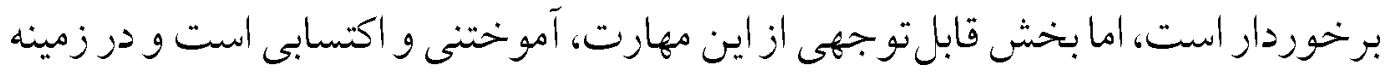

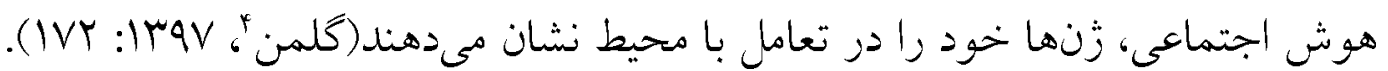


بههمين دليل، متخصصان و كارشناسان امر، كتابهاى كاربردى زيادى در اين زمينه

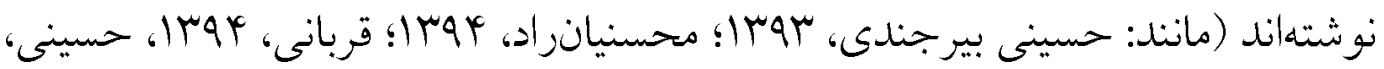

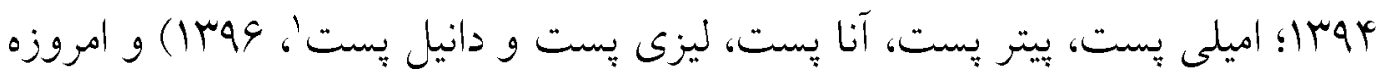

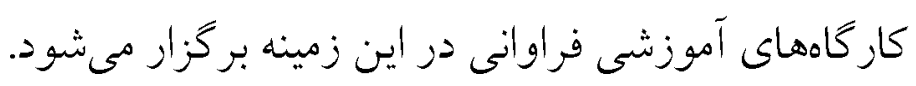

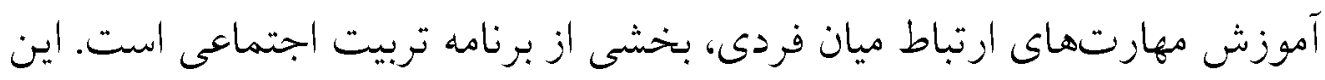

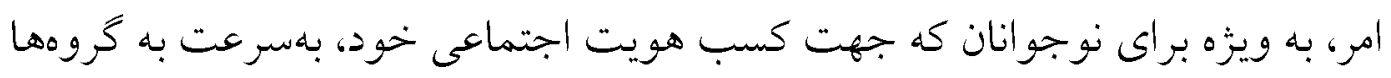

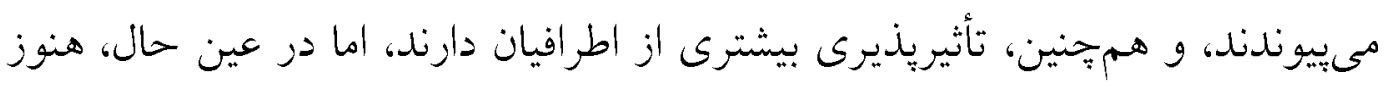

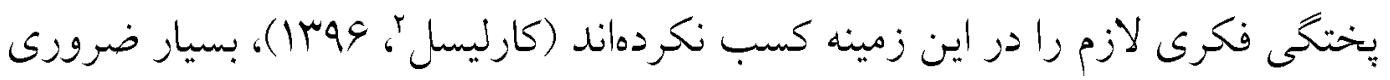

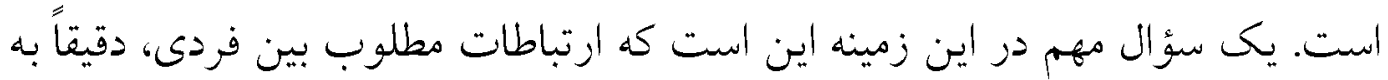

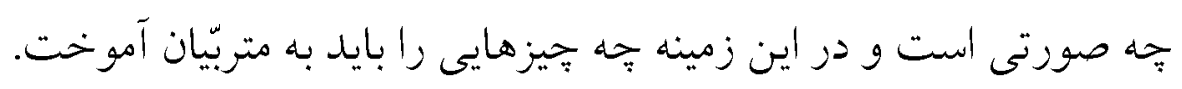

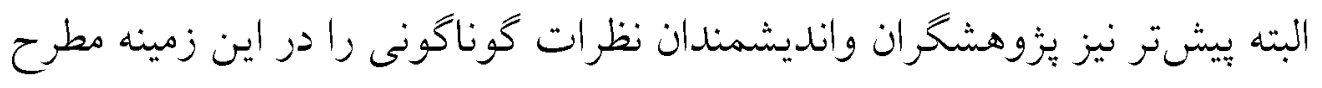

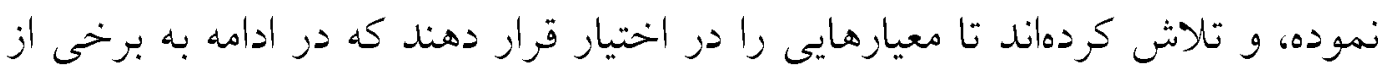

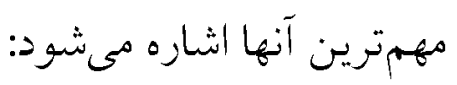

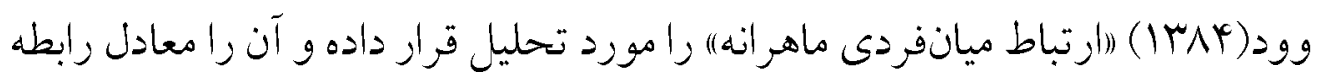

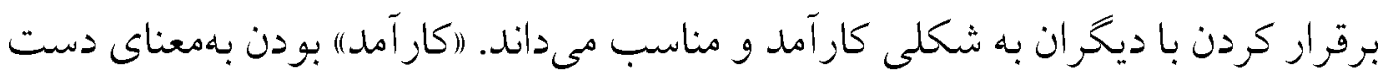

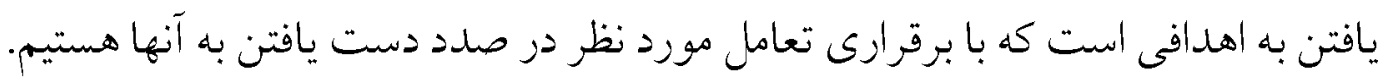

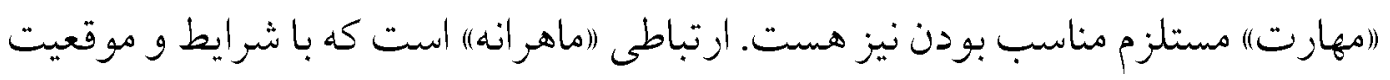

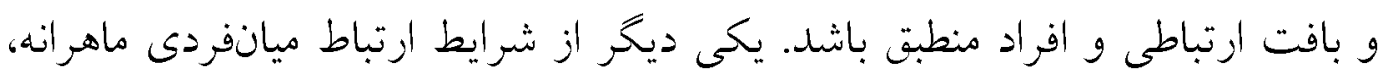

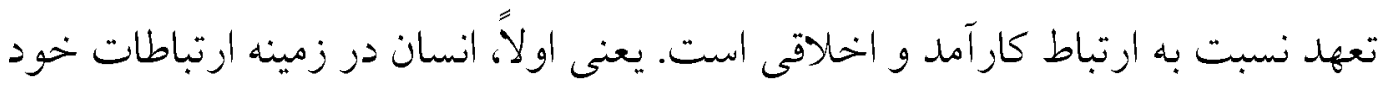

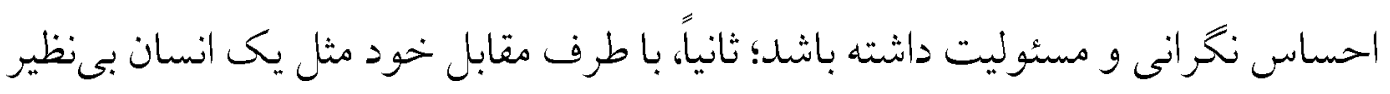

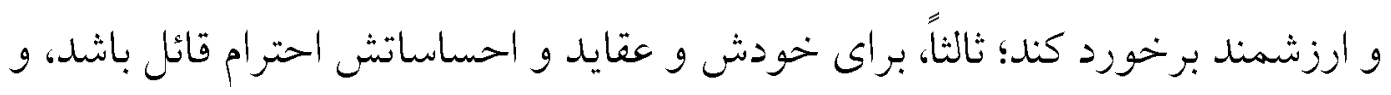

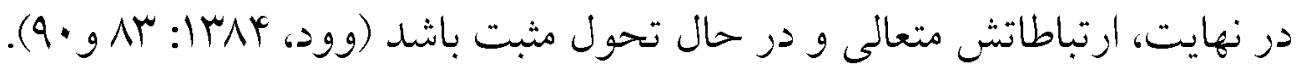

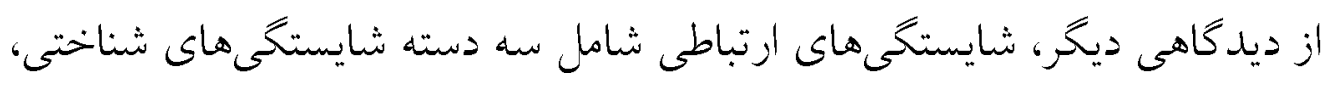

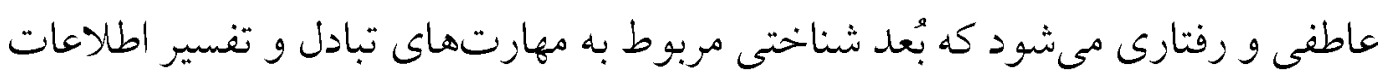

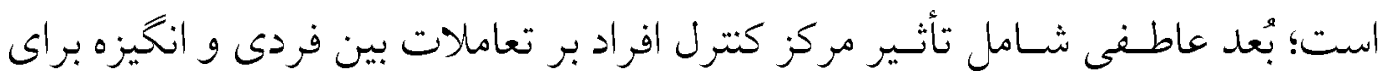

1. E. Post, P. Post, A. Post, L. Post, \& D. Post

2. Carlisle 
اصول (أوتباطات ميان فردى)) بر اسلاس

ديدكاه علاهـ حلى و استخراج دلالت هاي تربيتى آن

TrT-149

ارتباط بنطور شايسته و نزيكى شدن يا اجتناب از موقعيتهاى ويزه يا دستيابى بـ اهداف خاص در تعاملات است؛ و بعد رفتارى مربوط به مهارتهايى براى انتخاب و اجراى استراتزىهاى مناسب براى زسيدن به اهلاف شخصى است (يبيسا و تارجا'،

به نظر مىزسل كه زمينههاى مناسبى براى فعاليت و نظريهيردازى در عرصةٌ ارتباطات

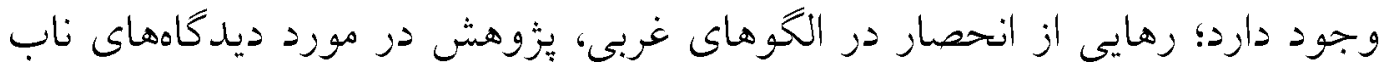

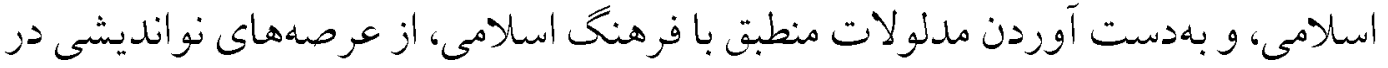

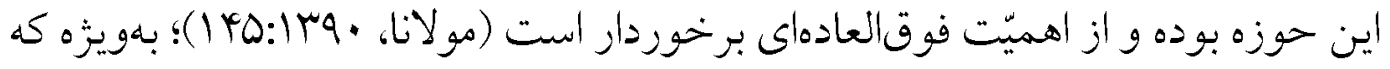
بـنظر مىرسد سبكهاى تعاملى در اسلام و غربب به دليل تفاوت دز بنيادهاى فلسفى و

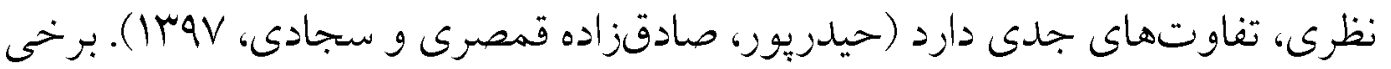
از مهمترين ديدكاههاى صاحبنظران كشورمان در اين زمينه بلدين قرارند:

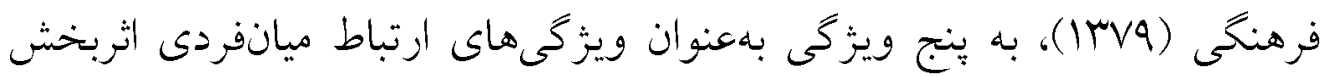

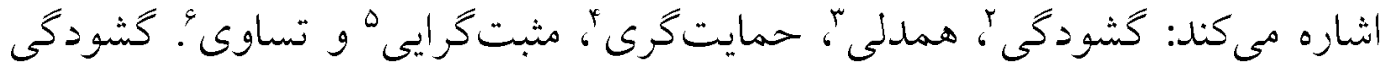

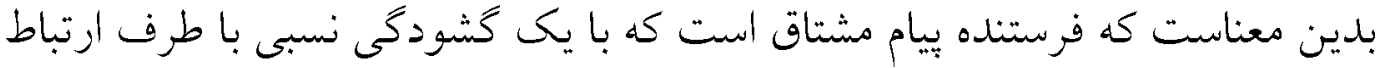
مواجه شود و اكاهانه و كترل شده، احساسات و تفكرات خود را به اطلاع مخاطب مىزساند. همدلى يعنى احساسى را تجريه كرين كه ديخرى نيز همان احساس را تتجربه

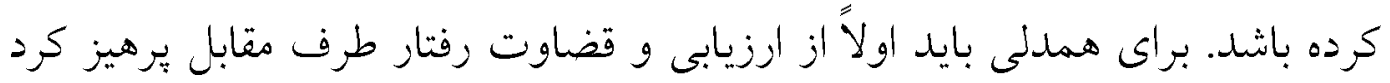

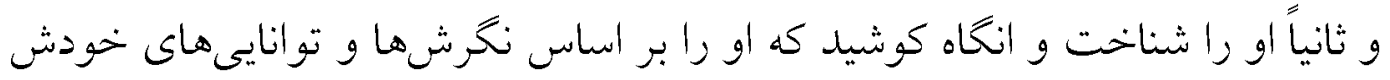
تجربه نمود. حمايتگرى نيز بادين معناست كه خوز را از نظر پِايخًاه اجتماعى در تراز مخاطب خوخ قرار دهيم و از نشان دادن برترىهاى خود به او يرهيز كنيم؛ براى اين كار لازم است ميزانى از تريد و علدم يقين راو علدم جزميت رادر ييش كرفت تا اين فرصت را به مخاطب بلهيم كه خود را نشان بلهد و ارزيابى كند. در مثبت كرايى نيز هم نسبت به خود و هم نسبت به طرف ارتباط احساس مثتى داريم و احساس مثتى 
هم بهدست مى آوزيم. هـمجنين، تساوى به معنى حاكميت فضايى مبتنى بر تساوى،

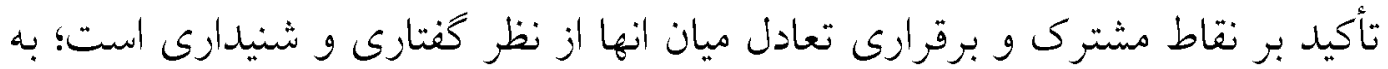

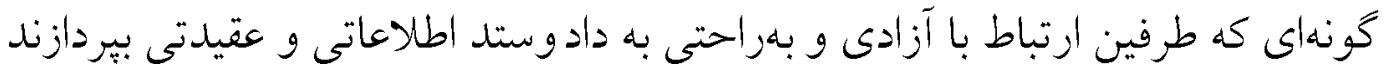

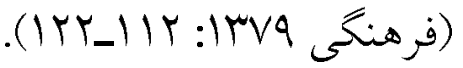

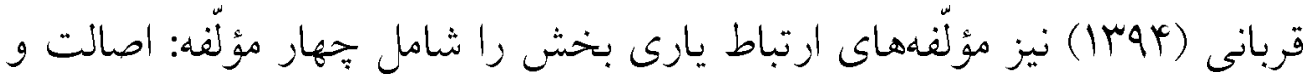

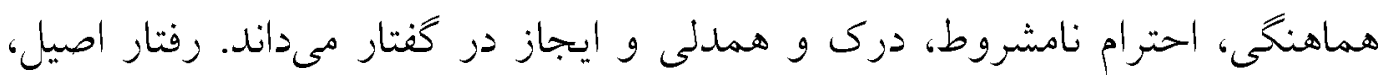

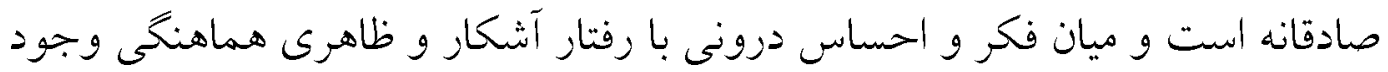

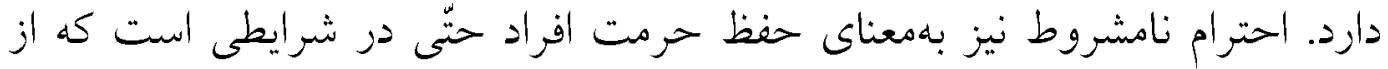

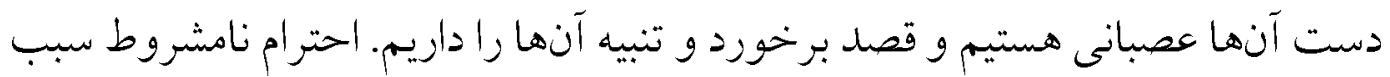

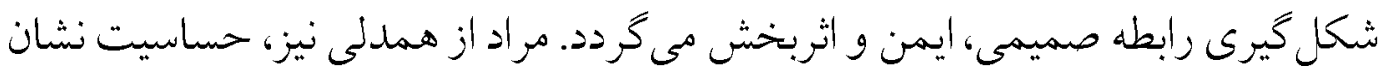

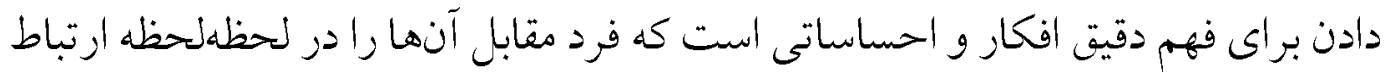

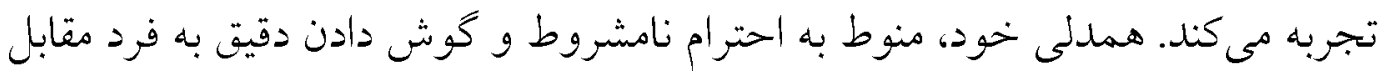

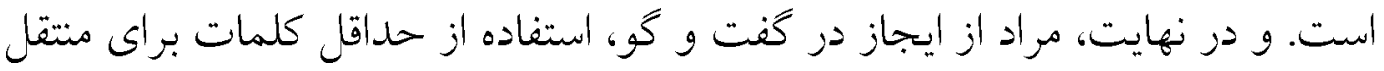

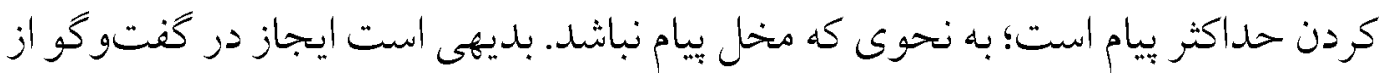

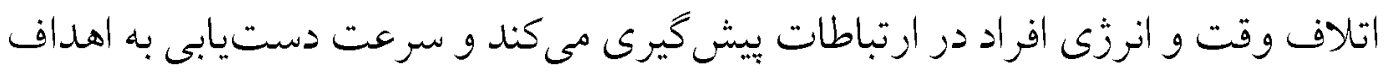

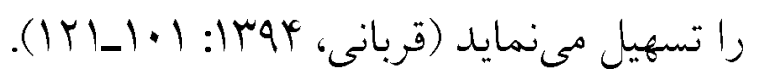

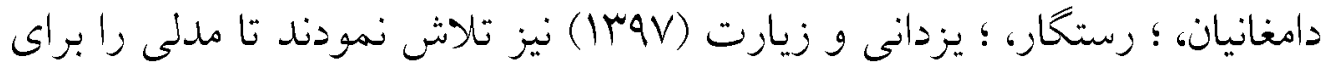

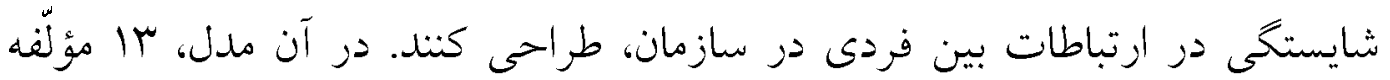

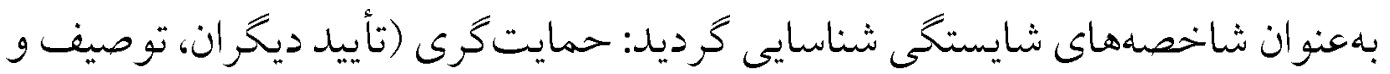

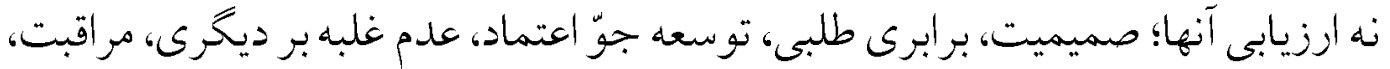

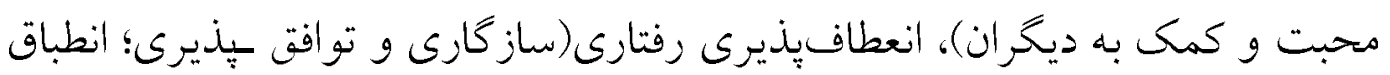

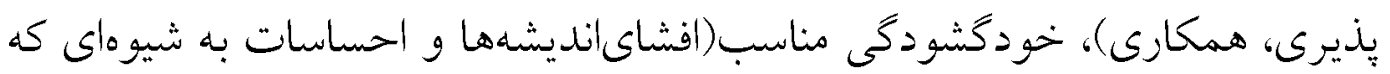

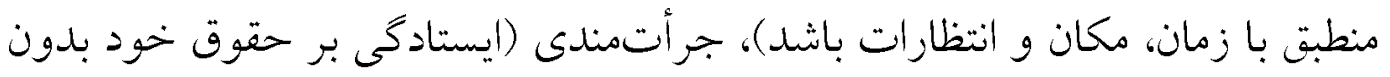

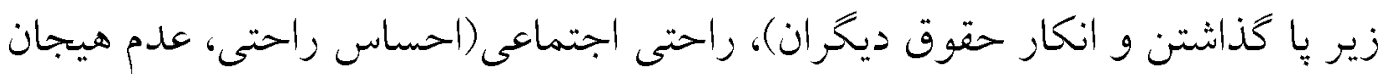

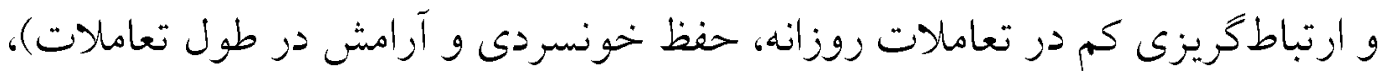

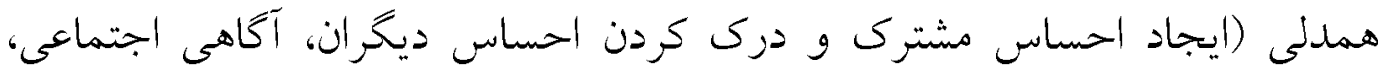

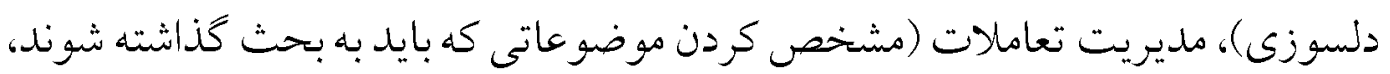


اصول (أوتباطات ميان فردى) بر اسلاس

ديدكاه علاهـ ملى و استخراج دلالت هائ تربيتى آن

Irr-1F9

رعايت نوبت، شروع و يايان كفتو كو، توسعه موضوعات كفتو گو، تغيير موضوعات)،

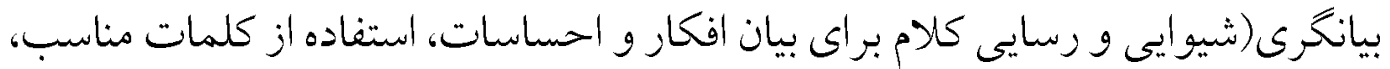

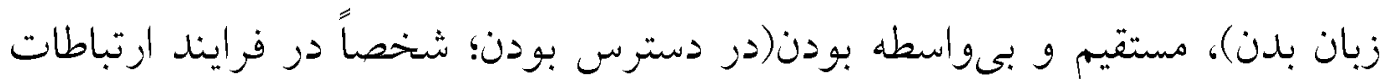

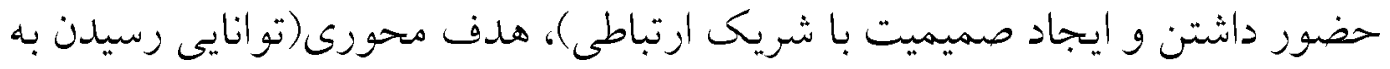
اهداف از ييش تعيين شده و كسب لذت و زضايت از ارتباط؛ اثربخشى، كنترل محيطى،

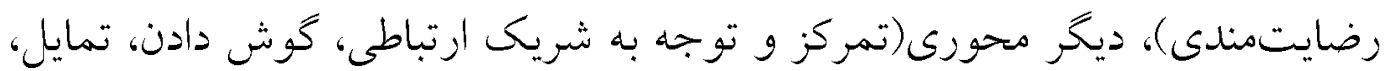

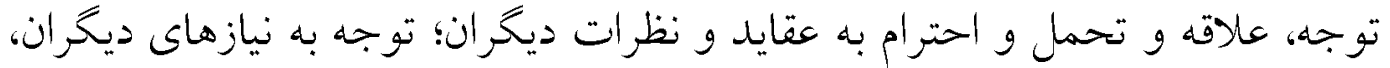

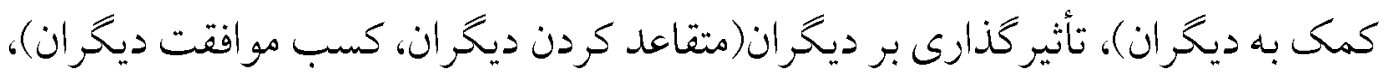
و مديريت تعارض(شناسايى حوزههاى توافق و عدم توافق، مديريت حل مسأله، مدارا، مديريت تنوع و تعارض، تحمل ابهام).

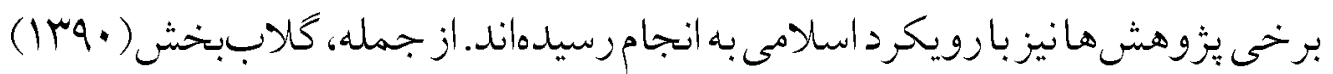

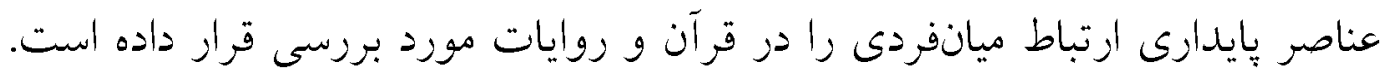

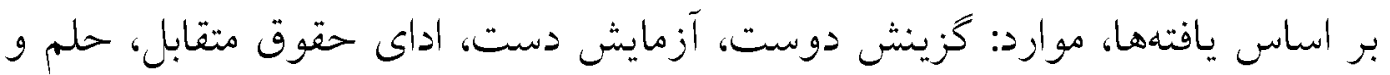

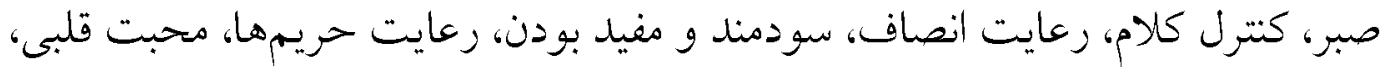

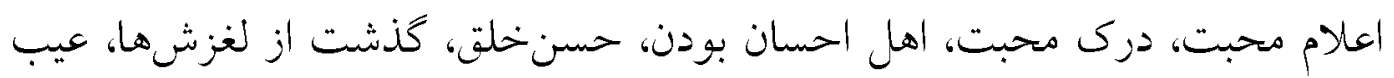

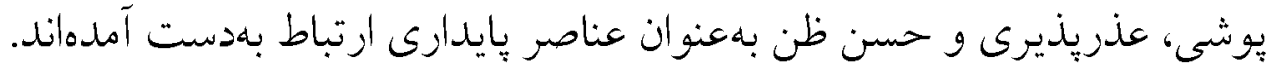

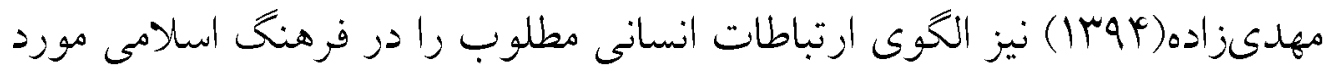

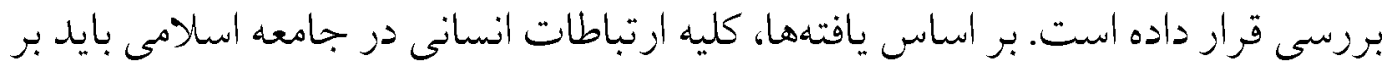

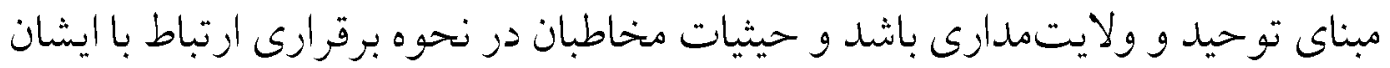

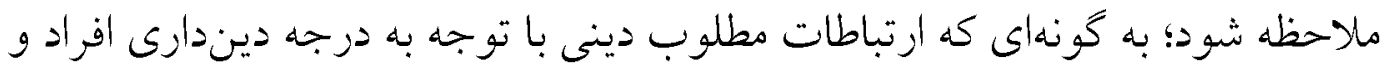
تولى و تبرى شكل بخيرد.

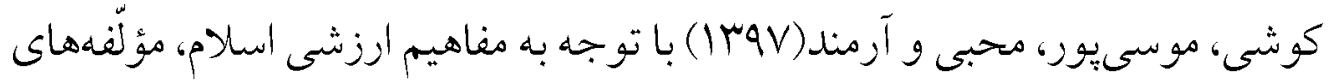

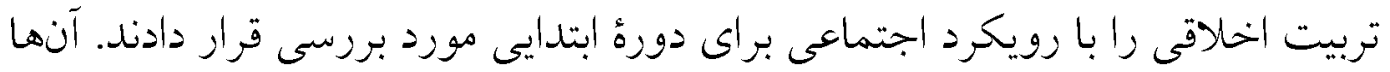

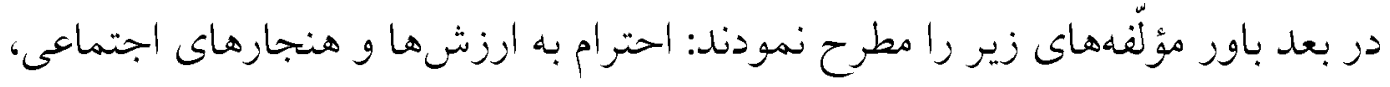

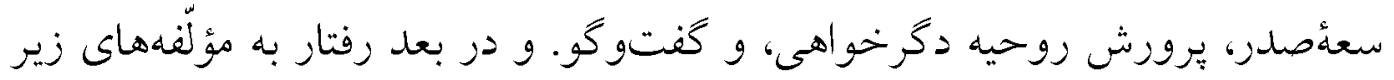

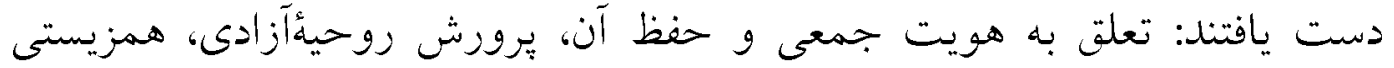

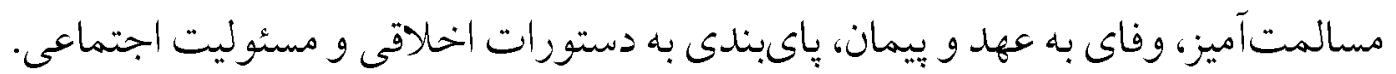


با تأمل در آثار موجود مىتوان دزيافت كه تا كنون اقدامات ارزشمندى انجام شدهو

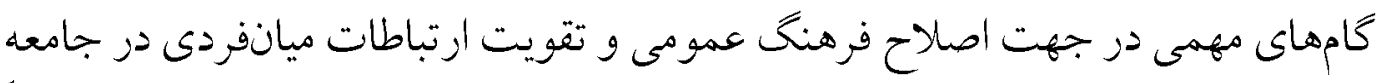

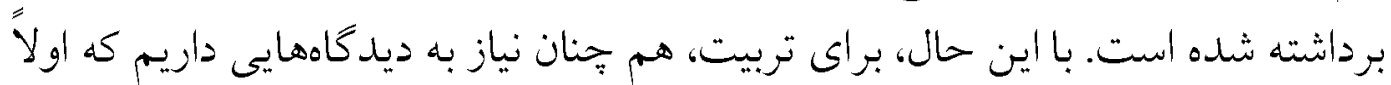

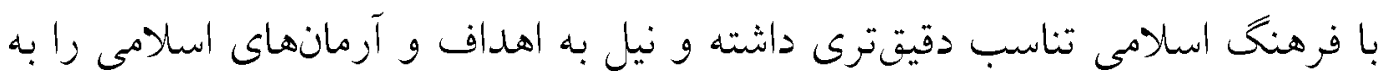

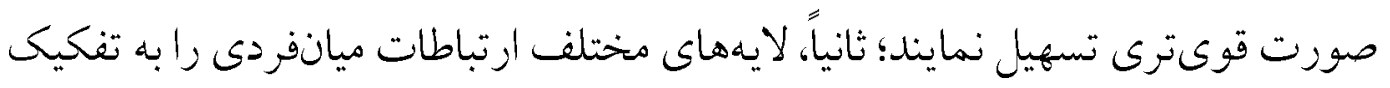

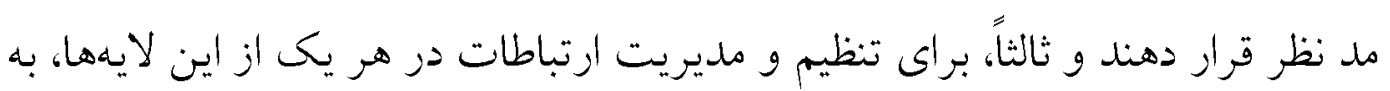

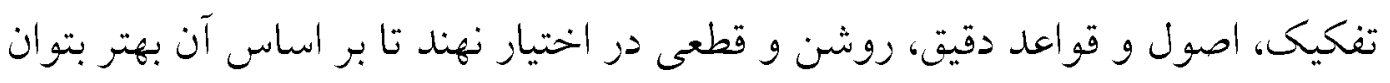

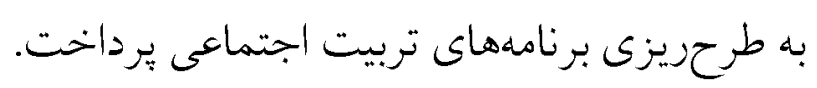

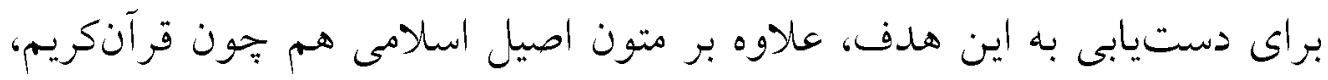

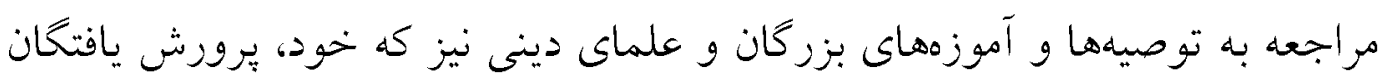

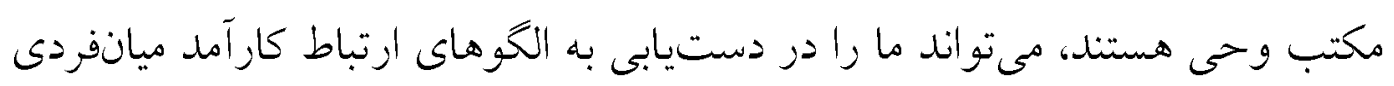

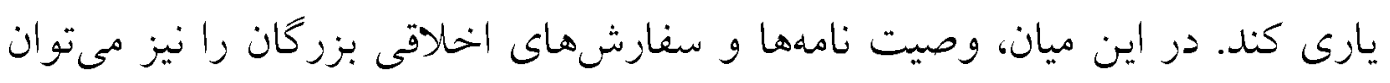

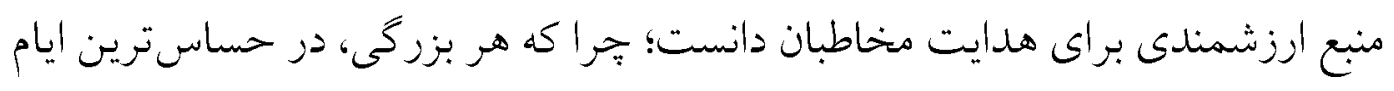

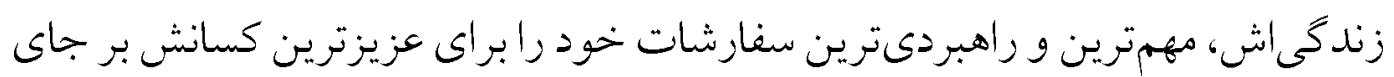

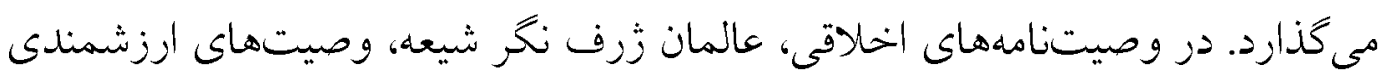

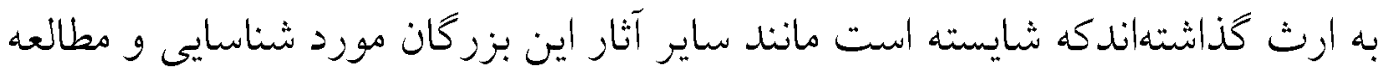

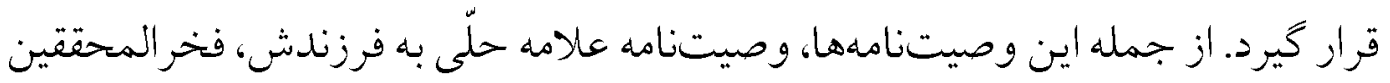

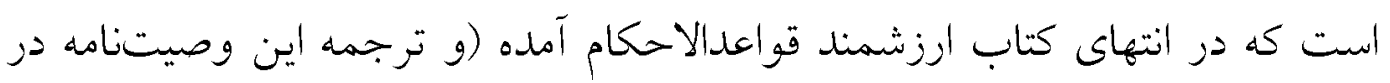

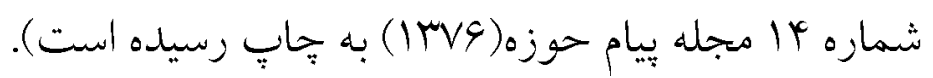

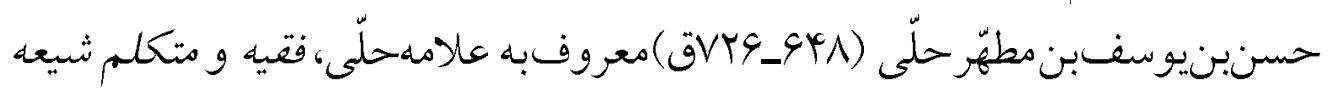

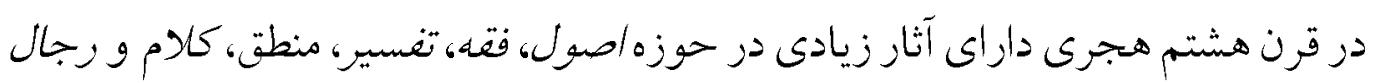

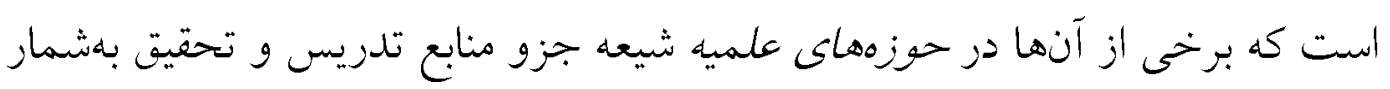

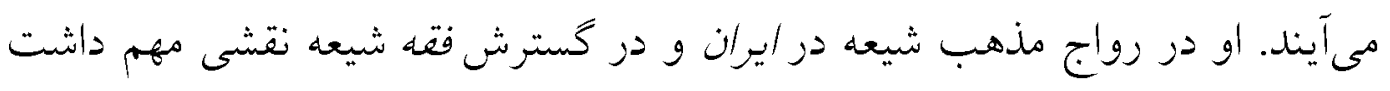

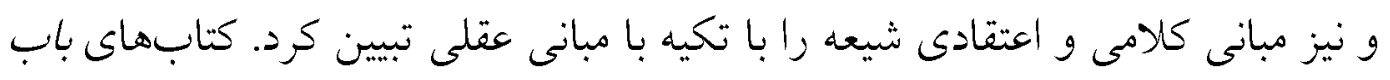

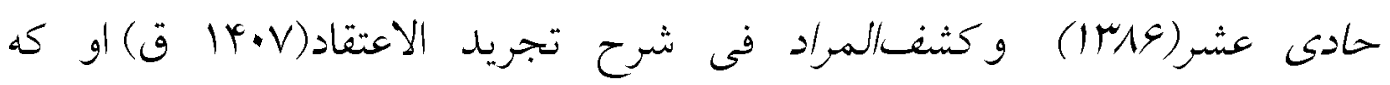

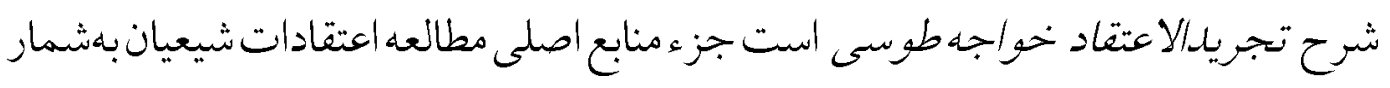

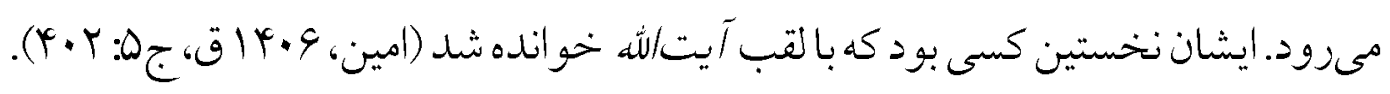


أصول (ارتباطات ميان فردى)) بر اساسي

ديدكاه علامه حلى و استخراج دلالت هاي تربيتى آن

1rr-148

از علامه حلّى يكى وصيتنامه كم حجم ولى بر مغز نيز بر جاى مانده است.

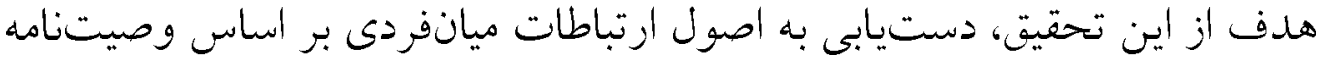

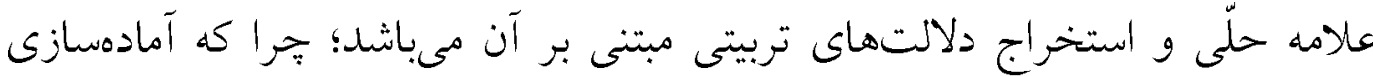

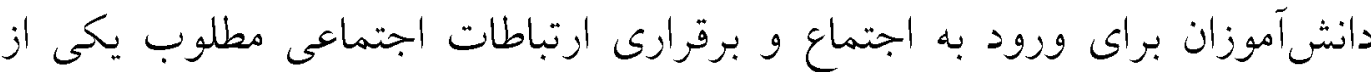

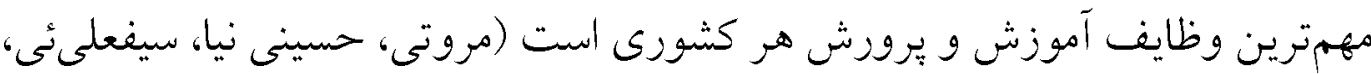

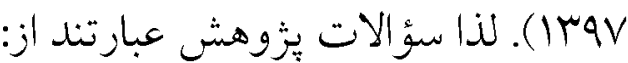

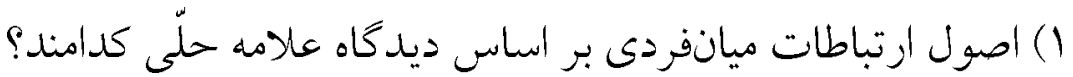
Y) جه نسبتى ميان (ارتباطات ميان فردى" با "ازتباط با خدا)" و "ازتباط با خودة)

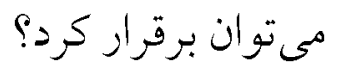
r) بر اساس يافتهها، جهه اصول تربيتى را براى يرورش مهارتهاى ارتباطات ميانفردى مىتوان مطرح نمود؟؟

\section{روش بزوهش}

اين تحقيق با رويكرد كيفى انجام كرفته، شيوه كردآورى اطلاعات، شيوه اسنادى است.

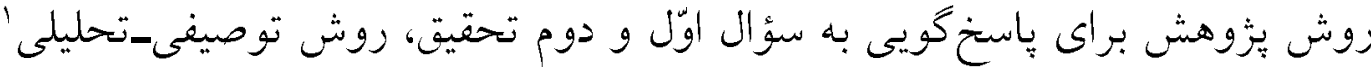

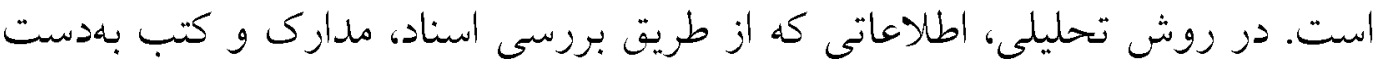

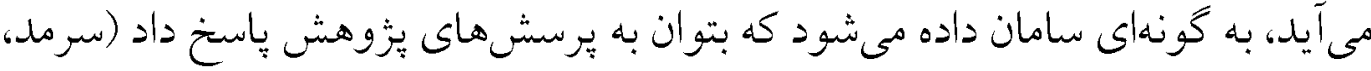

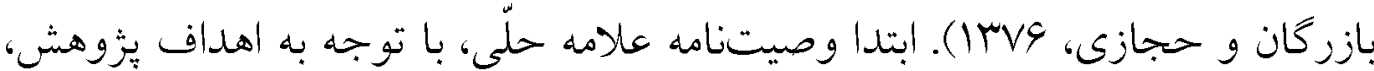

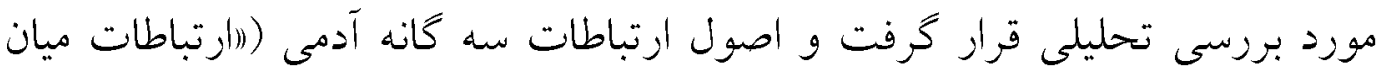

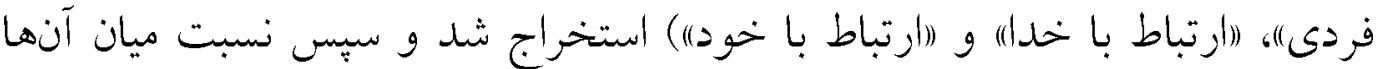

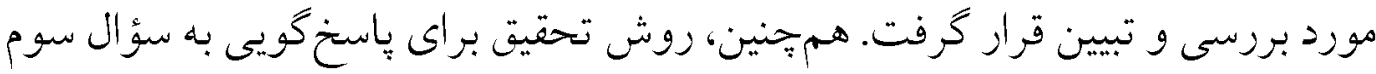

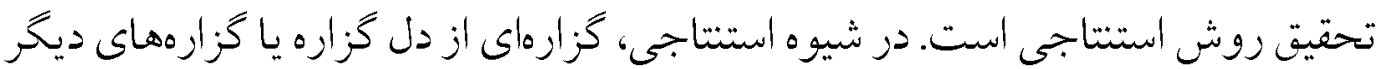

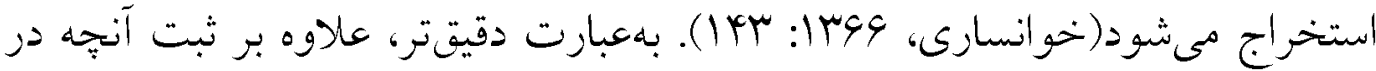

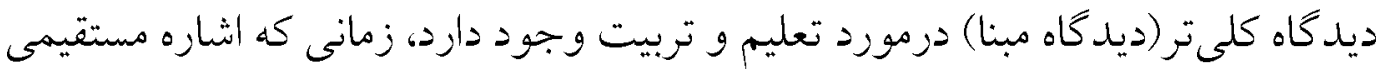

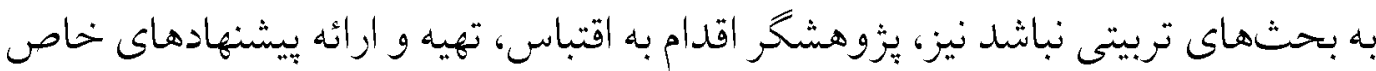

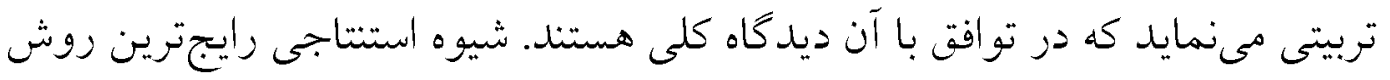




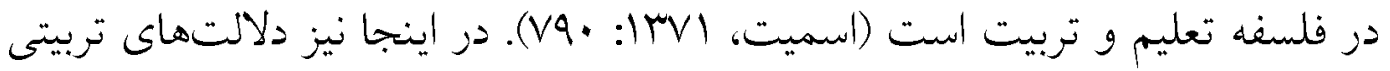
بحث براى تقويت مهارت ارتباطات ميانفردى (در قالب اصول تربيتى) استتاج شدهاندا.

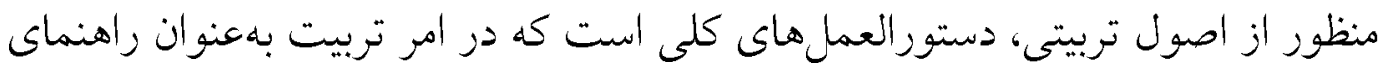

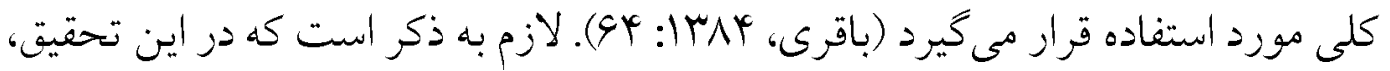

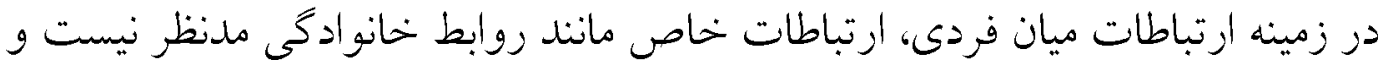

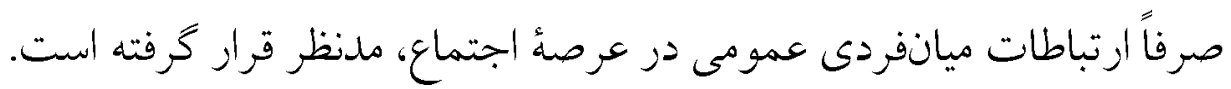

\section{سطوح ارتباطى و اصول آنها، بر اساس ديدكًاه علامه حلّى}

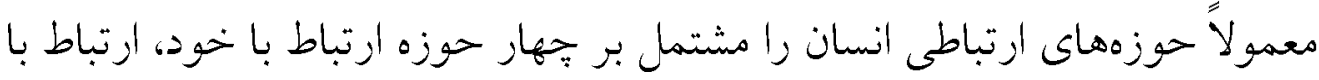

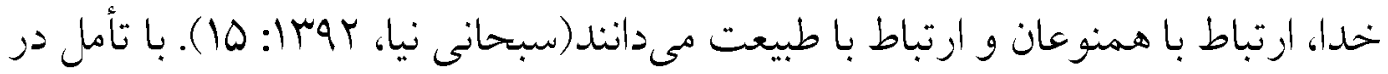
مفاد وصيتنامه علامه به يسرش نيز مىتوان حست كم سه سطح از ارتباطات را استنتاج نمو2.

\section{اول ـ اصول ارتباط با خداوند:}

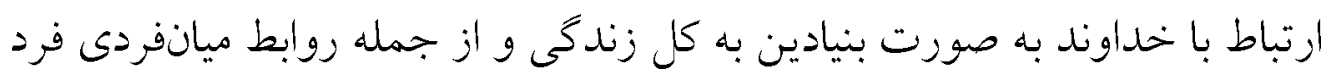

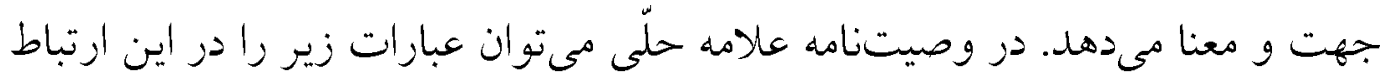
مورد توجه قرار داد:

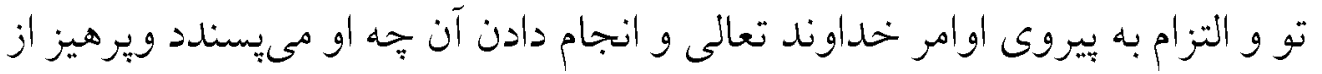

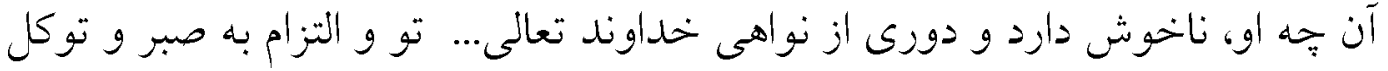

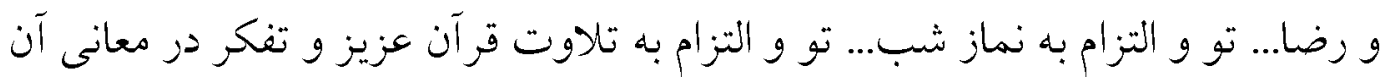

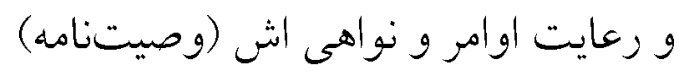

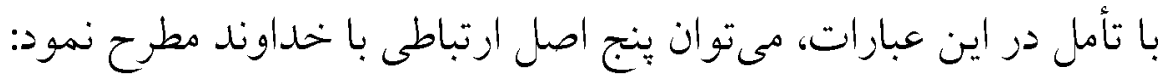

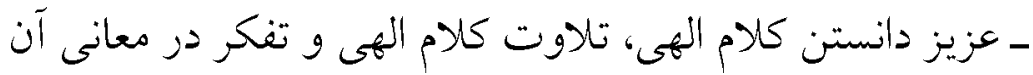

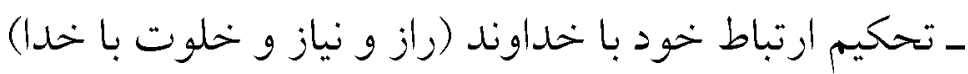

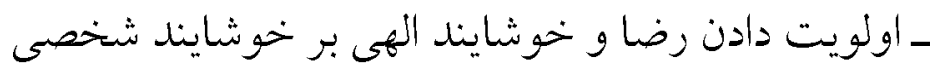

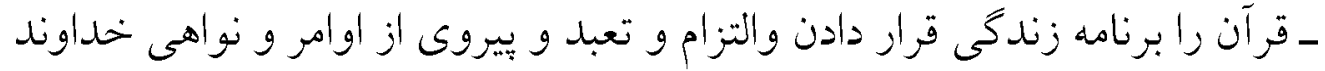

$$
\text { ـ صبر و توكل و رضا براسل }
$$


اصول (أوتباطات ميان فردى)) بر اسلاس

ديدكاه علاهـ هلى و استخراج دلالت هاي تربيتى آن

1rT-148

همان كونه كه ملاحظة مىشوح، اولويت دادن مطلق به برنامه زندكى الهُى (در عالم

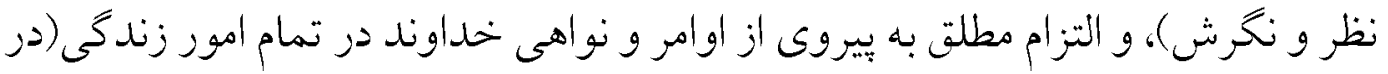
عالم عمل و زفتار)، مسير زندكى را به صوزت بنياين مشخص مئ كند و به تمامى فعاليتهاى زناكگى جهت مىبخشد؛ و البته اين مسيرى حشوار است كه جز با صبر و توكل و زضا نمىتوان آن را يميمود. در واقع، ساير ابعاد ارتباطى انسان نيز تحت تأثير اين آرمان، شكل مناسب خود زا خواهند يافت و توصيههاى علامه، با درك اين منبع جهت دهنده، معنادار خواهند شلد.

\section{دوم ـ اصول ارتباط با خويشتن}

رفتار ازتباطى درون فردى، عرصه مهمى از ارتباطات انسانى است و حتّى بر

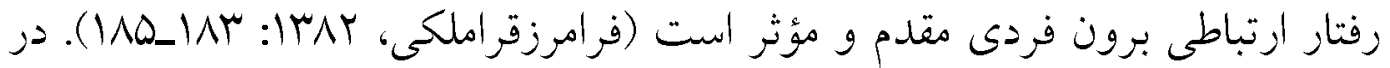
وصيتنامه عالمه حلّى مىتوان عبارات زير را در زمينه ارتباط با خويشتن مورد توجه لئه قرار داد: - مان

برايت وصيت مىكنم به اين كه همدوش با تقو اي الهُى باشى؛ كه آن، به يقين، السنت

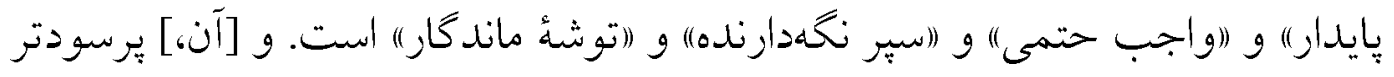
جيزى است كه انسان براى روزى كه هيشمها، از هيبت آن زوز، كشاده و خيره مىماند و يار وياورى نيست، خواهلد داشت... تو و التزام به بيروى اوامر خداوند تعالى و انجام دادن آن جهه او مىيسند ويرهيز از آن جِه او، ناخوش دارخد و دورى از نواهى خداوند تعالى... زندكىات رادز تحصيل كمالات نفسانى، سيرى ساز و اوقات ات را در "اكسب تهب فضايل علمى" و (اعروج از يستى نقص به بالاترين نتطة كمال)"و (اوج كيرى در آسمان

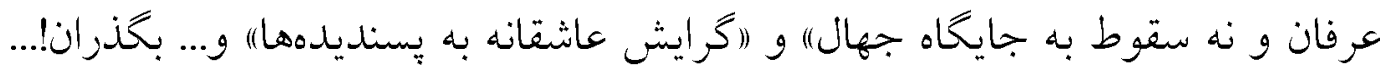
بايد، امروزت از ديروزت بهتر باشد... هـ روز و شب، محاسبهُ نفس كن! از خلاوند، بسيار آمرزش بخواها... تو و التزام به كوشش فراوان براى افزودن علمات و ززفنخرى

$$
\text { حر دين (وصيتنامه). }
$$

با تأمل حر اين عبارات نيز مىتوان ينج اصل براى ارتباط مناسب با خويشتن مطرح 
ـ معنويتكرايى توحيدى در اعمال و رفتار خويش (اولويت رضايت الهيى)

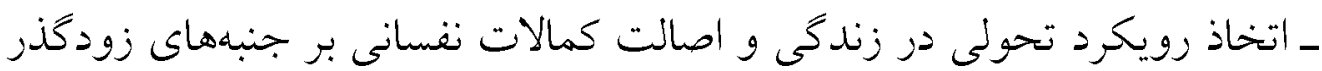
مادى

$$
\text { ـ خودمراقبتى، خويشتندارى و خودكتترلى إنى }
$$

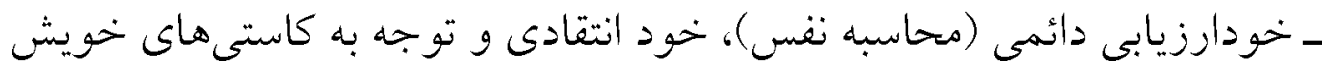

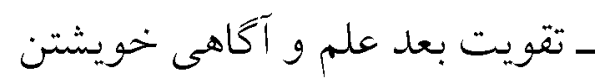

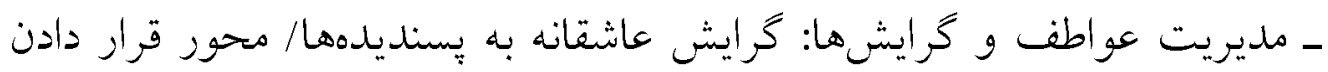

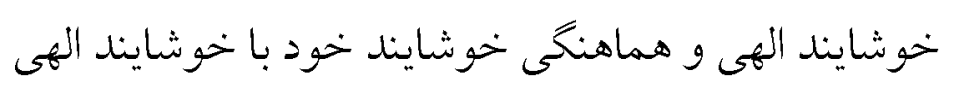

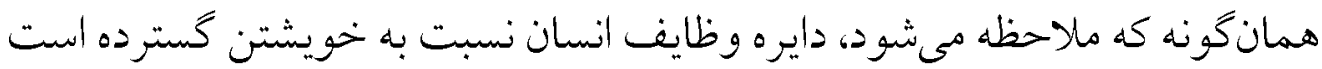

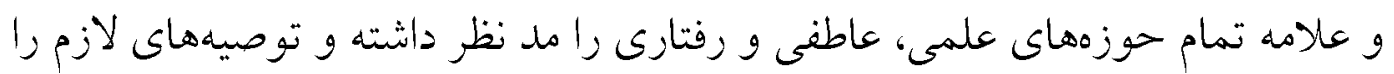

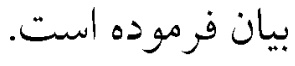

\section{سوم ـ اصول ار تباطات ميان فردى با توجه به سطوح ارتباطى}

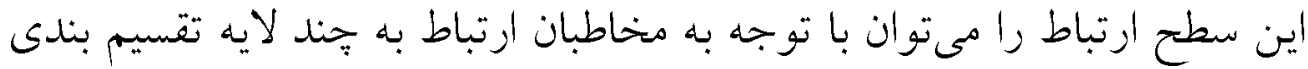

\section{ب-1) (1) ارتباطات عمومى در جامعه}

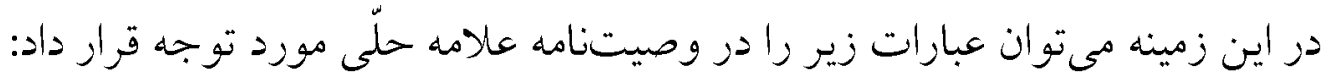

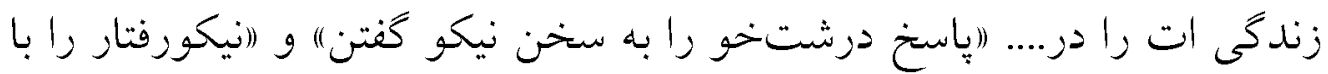

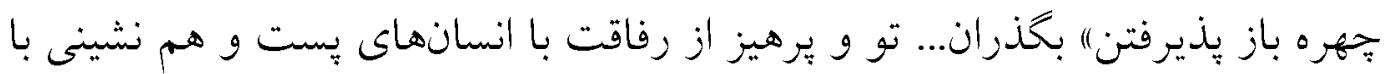

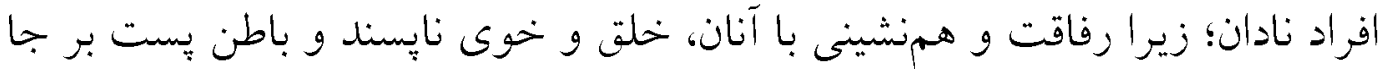

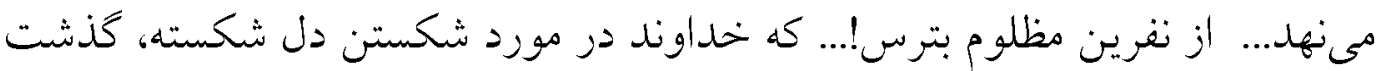

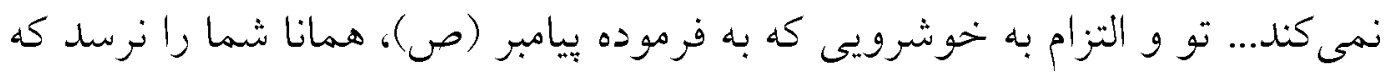

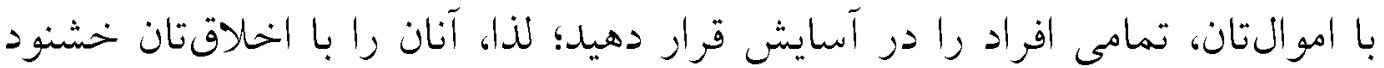

$$
\text { سازيد (وصيتنامه). }
$$

با تأمل در اين عبارات نيز مىتوانه جهار اصل براى ارتباطات عمومى در جامعد

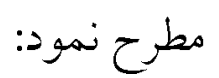

ـ كَادهرويى، خوش خلقى و خشنود كردن ديخران 
اصول (أرتباطات ميان فردى)" بر اسلاس

ديكاه علاهـ حلى و استخراج دلالت هائ ترييتى آن

TrT-149

ـ صبوزى، بزركوازى و اجتناب از مقابله به مثل ـ اجتناب از ظلم و آسيب رسانى به ديخران

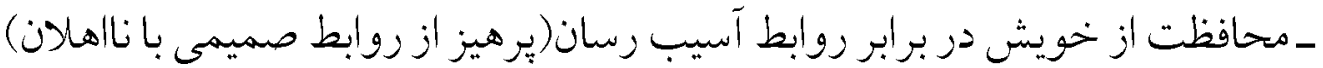
رعايت اين اصول منجر به رشد شخصيّتى در خود فرد، و از سوى ديخر، برقرازى

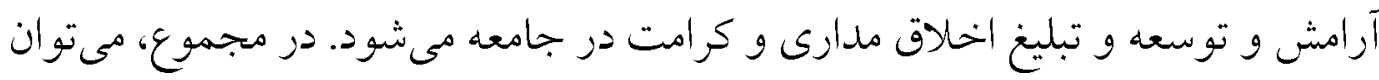
اين بخش را به صورت (احق مدارى، كرامت و مديريت) خلاصه نمود. "r- (T) ارتباط با برادران دينى

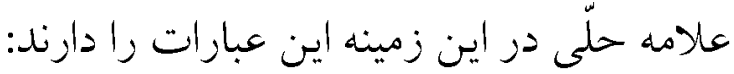

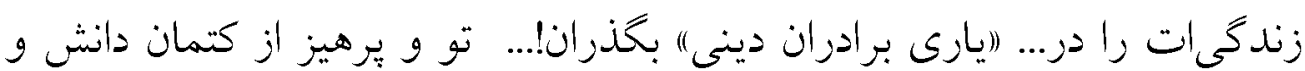
بازداشتن شايستخان از فراگيرى علمت (وصيتنامه)

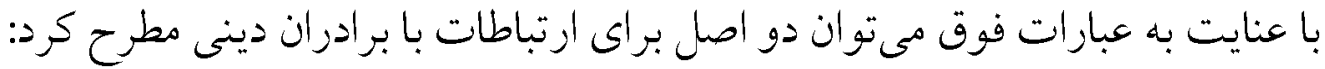
- زفتار ياريخرانه

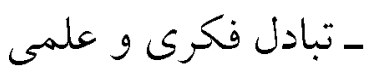
اين بخش رانيز مىتوان به صوزت (هميارى علمى و عملى) خلاصه نمود. مشاركت

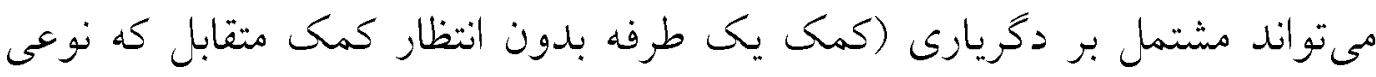

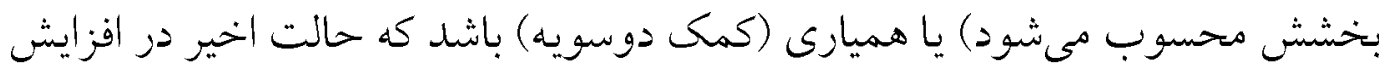

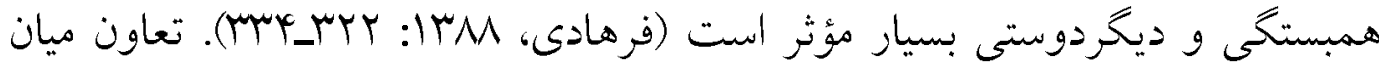

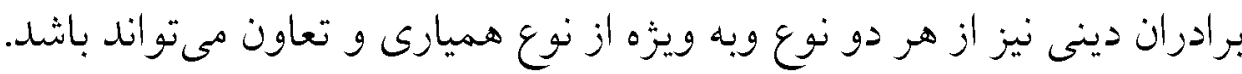

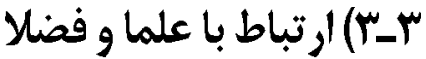

حر زمينهُ نحوهُ ارتباط با علما و فضلا مىتوان عبارات زير رادر وصيتنامه علامه حلّى موزد توجه قرار داد: 
و اهانت كند، يز قيامت، خدا را، ناراضى وخشمخين از او، خواهد يافت. و نيز حضرت

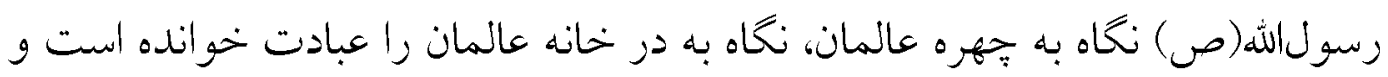

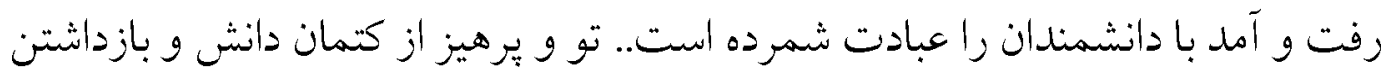

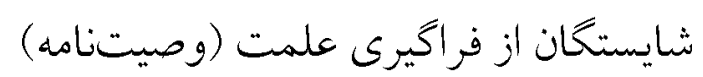

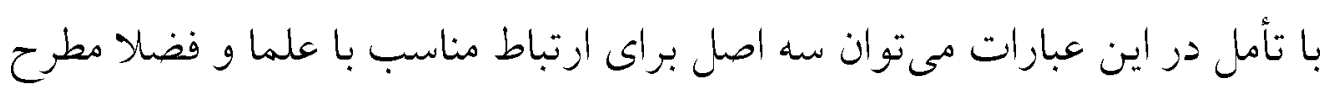

$$
\text { كرد: }
$$

ـ مجالست و موانست با عالمرانيز

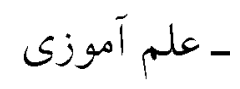

اين بخش از ارتباط ميانفردى را مىتوان ارتباط علمى دانست. (ارتباط علمى" به ديه

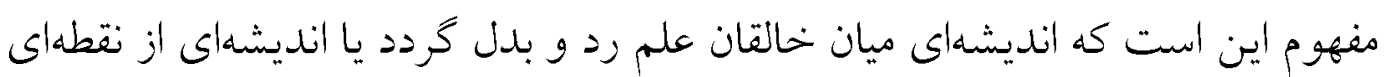

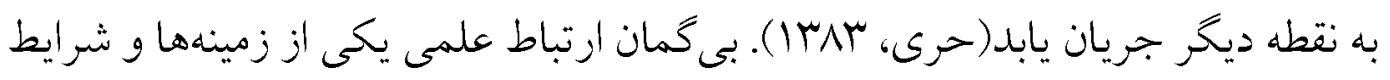

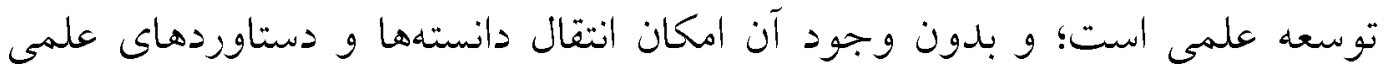

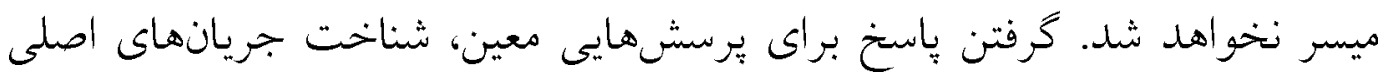

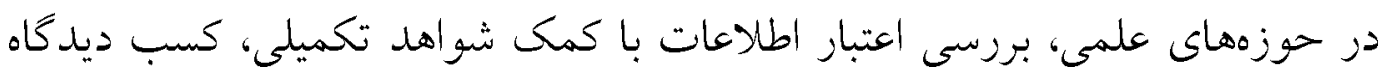

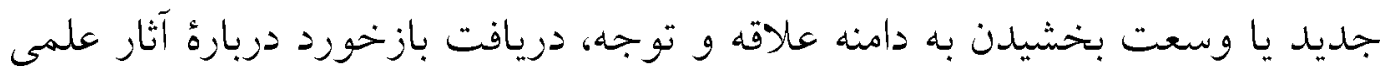

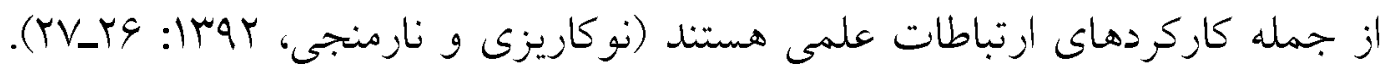

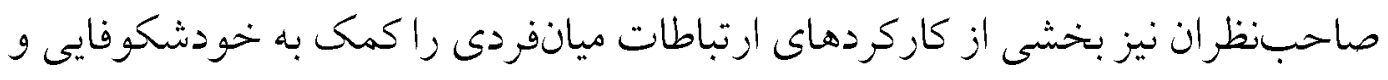

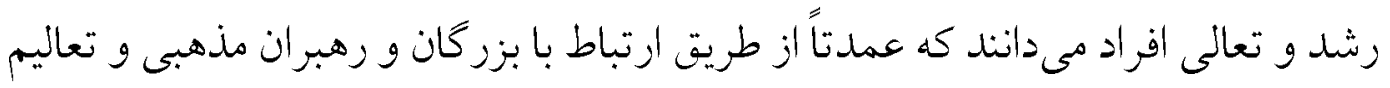

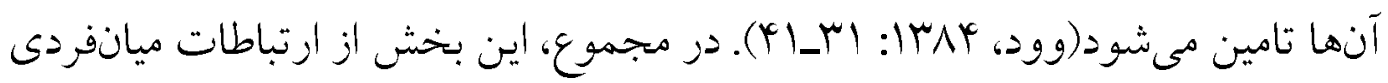

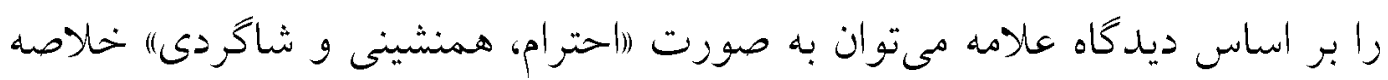

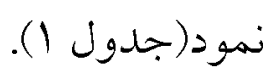




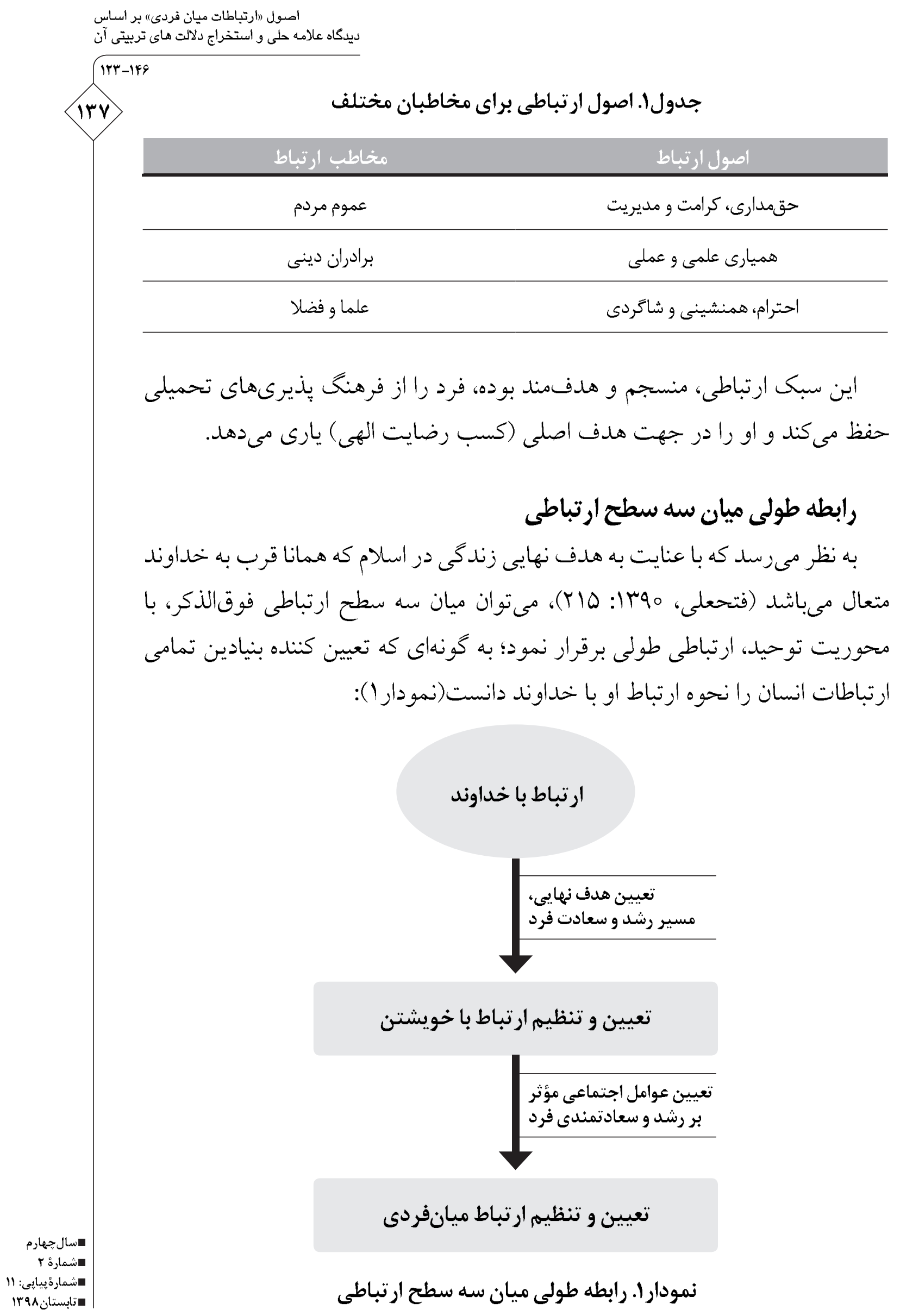


در اينجا نحوة ارتباطات با توجه به لهدف" ازتباط مشخص مىشود. و با وضعيت

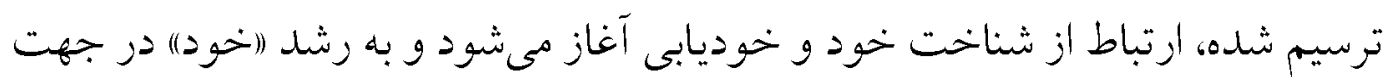

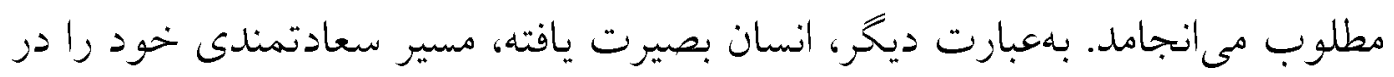

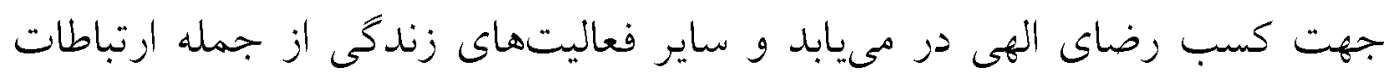
ميانفردى رانيز بر همان اساس تنظيم مى كنئد.

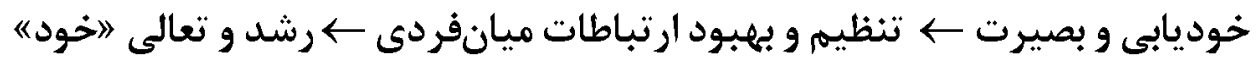
در نخاه علامه حلّى، تكى تك كنشهاى ارتباطى با توجه به هدف ارزشى، مهندسى

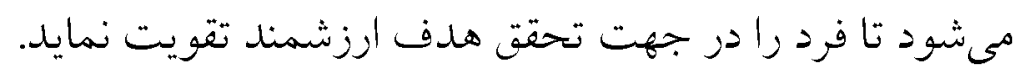

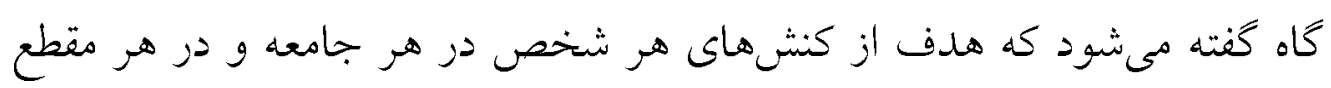

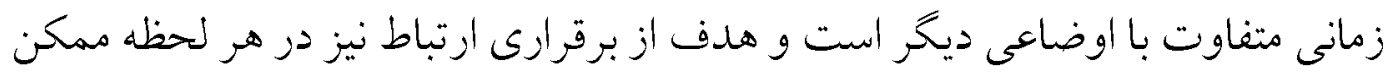

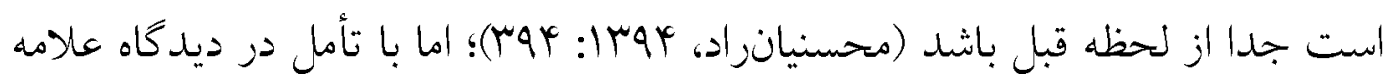

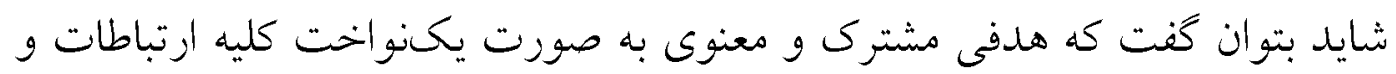

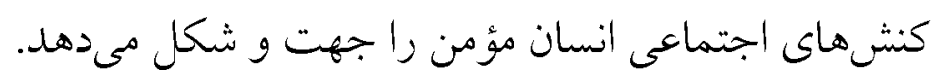

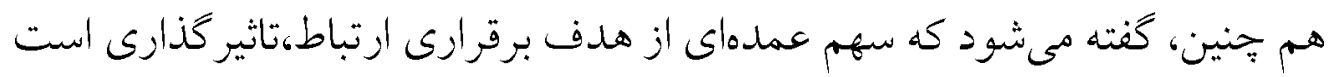

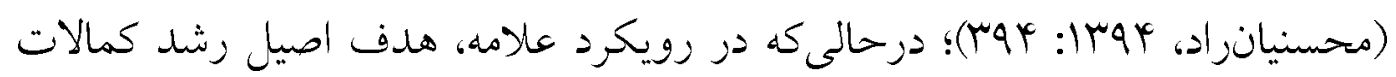

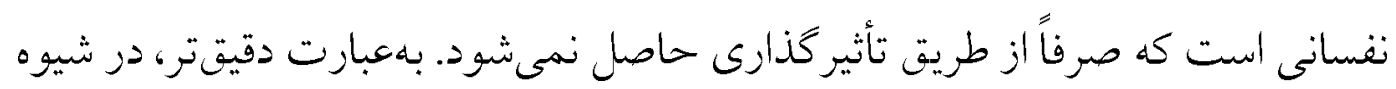

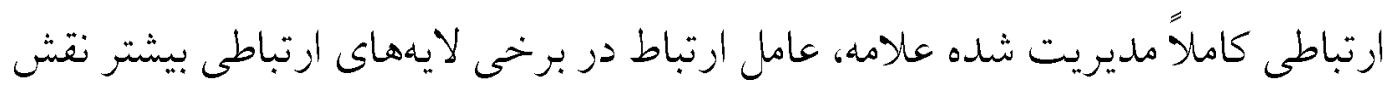

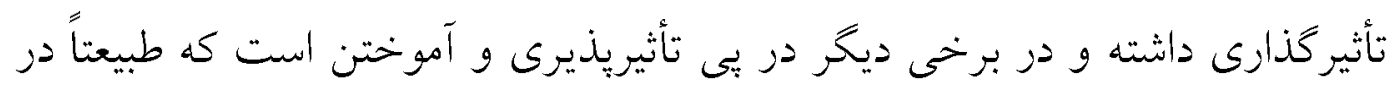

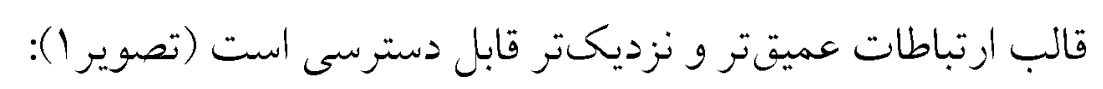

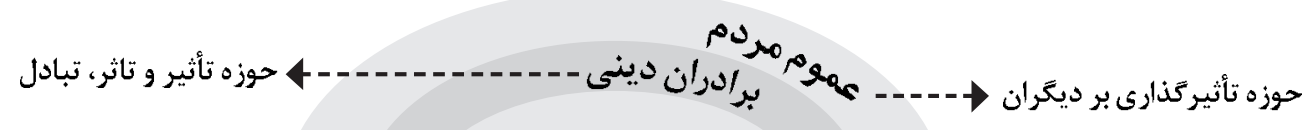

حوزه تأثيريذيرى، تواضع و تبعيت \ـ--_-

تصويرا. حوزههاى تأثير كذارى و تأثير يذيرى در سبك ارتباطى علامه حلّى 
اصول (أرتباطات ميان فردى)" بر اسلاس

ديدكاه علامه حلى و استخرائ دلالت هاى تربيتى آن

TrT-149

بلدين ترتيب، علامه فراينادهاى تأثيركذارى/تاثيريذيرى زأبهخوبى مليريت مى كند. لزر اينجا ارتباط ميانفريى مجموعهاى از فر ايندهاى هوشمنادانه و مديريت شده بر اساس هاف است. همانكونه كه صاحبنظران، اهداف را حر ارتباطات مهمترين مالحى براى

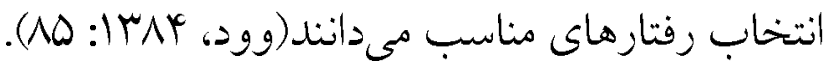

\section{اصول تربيتى بر مبناى ديدكاه علامه حلّى}

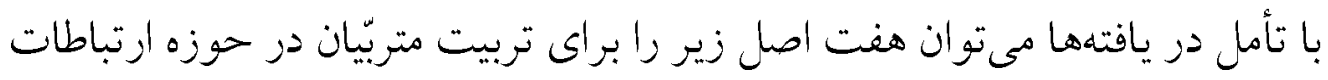
ميانفريى در نظر كرفت:

\section{خدامحورى:}

توحيل، روح كلى حاكم بر فرهناً اسلامى است و به همه جنبههاى فردى و اجتماعى زندكى از جمله، ارتباطات ميانفردى جهت مىبخشد. متقابالًا ارتباطات اجتماعى نيز بستر و وسيله كسترش و تعميق معارف و ارزشهاى اصيل اسلامى هستند. در جنين فضايى، توصيه مىشود كه قاعله كلى حاكم بر ارتباطات انسانى، توحيد، ولايتمدارى

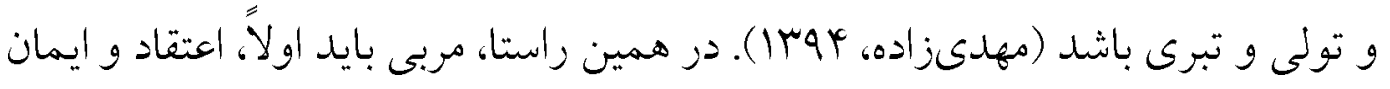
به توحيل، عشت و محبت الهى و اولويت بخشيدن به رضايت الهي نز تمام موارد زندكى از جمله در سبك ارتباطى خويش در جامعه را در متربيّان تقويت كنند. اين موزد را مىتوان اصل اساسى در تربيت اجتماعى متربيّان حر نظر كرفت؛ زيرا بقيه اصول نيز به نوعى متكى بر همين اصل بنيادين هستند.

\section{هقل معرايى:}

با عنايت به تأكيد بر خويشتندارى، كنترل هيجانات و تكانهها و گزينش عقلانى واكنش ها، جهت مديريت صحيح ارتباطات، حاكميت قواى عقلانى در كنشهاى فردى امرى ضروزى به نظر مىرسل. بلدين ترتيب، يكى از برنامهها و اقلامات اساسى مربى بايد تقويت قوه عقل و مديريت هيجانات و احساسات دز متربيّان باشد.

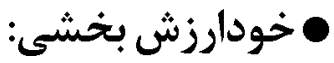

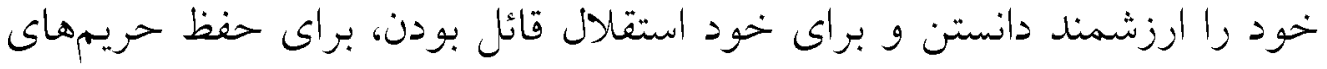


زفتارهاى افراد داشته، به آنها كمك مى كند تا در تمام جنبههاى زندكى خود معقولانه تر

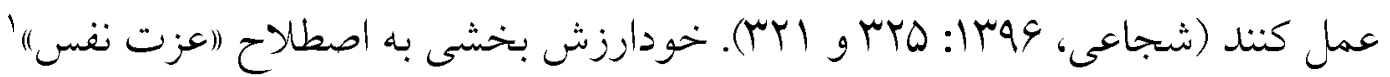

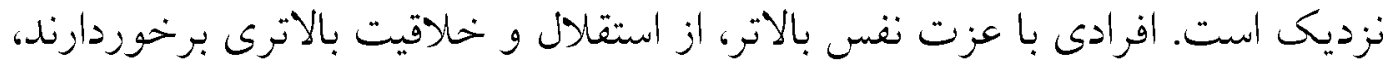

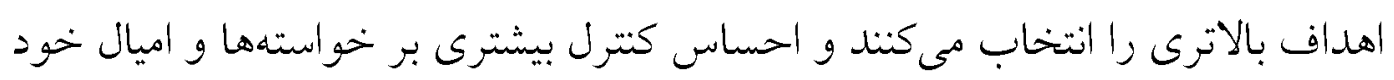

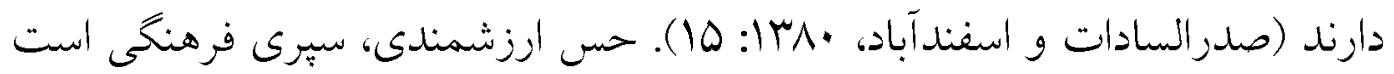

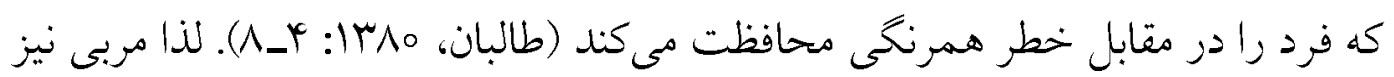

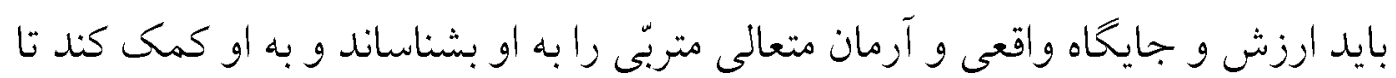

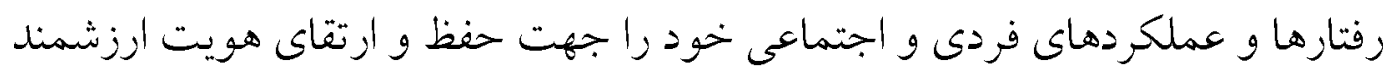

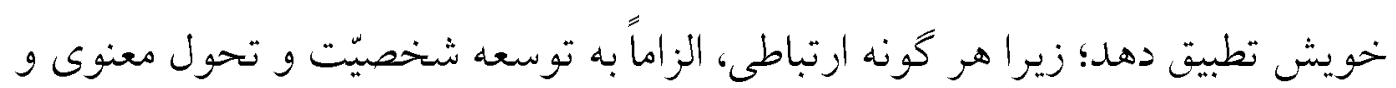

$$
\text { حتّى دنيوى انسان منجر نمى شيود. }
$$

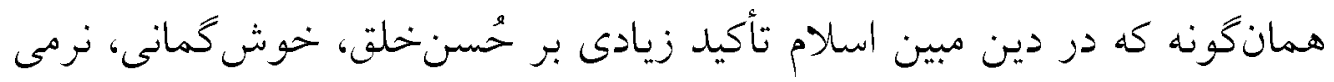

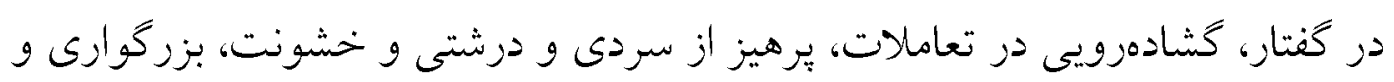

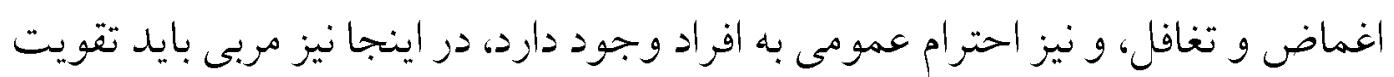

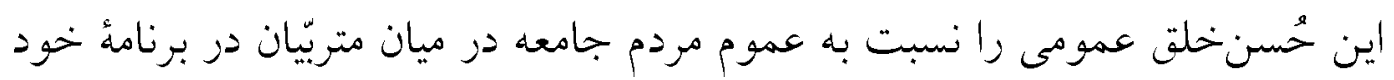

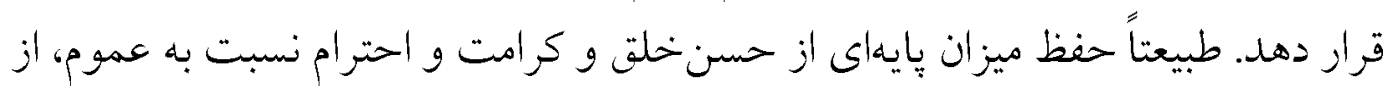

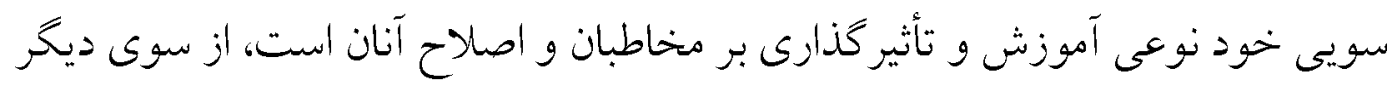

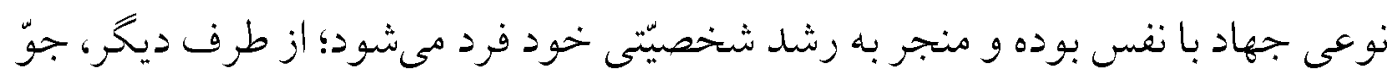

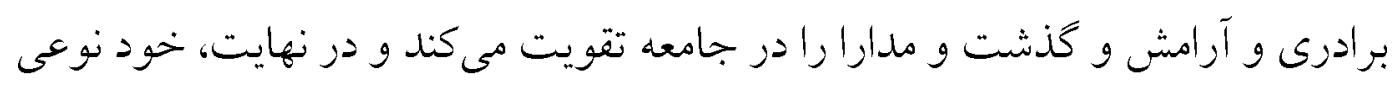

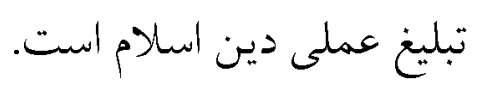

\section{• • بانتخابكرى:}

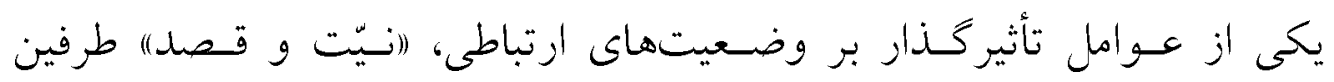

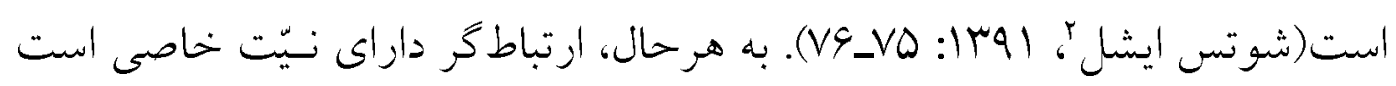

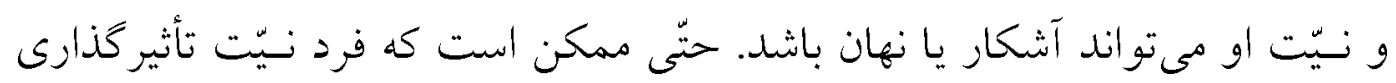

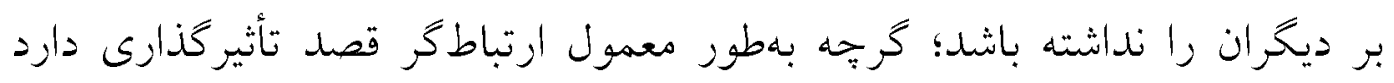


اصول (أرتباطات ميان فردى)" بر اسلاس

ديدكاه علاهـ حلى و استخراج دلالت هاي تربيتى آن

TrT-149

(بليكى وهارولدسون، مهب|: 99) و تلاش مى كند تا ديخرى را به نوعى تحت كنترل

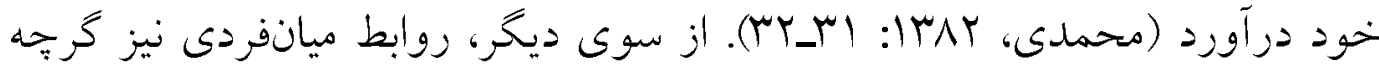
ابتدا نايايدار است، اما افراد كمكم اين ارتباط را تقويت مىكنند و ممكن است

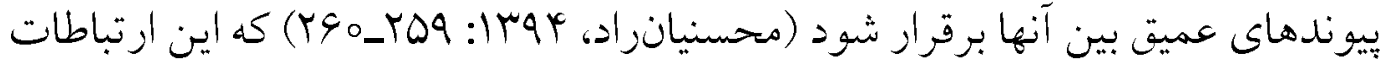

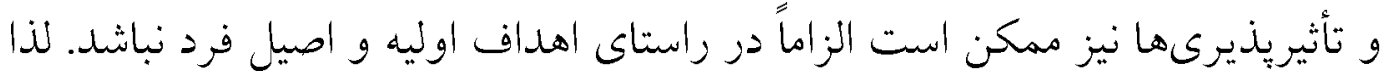
مربى بايل به متربيّان ياد دهد كه براى رسيدن به اهداف خاص خون و و يا حفظ مسير درست خويش، لازم است طرف ارتباط را نيز حر همان راستا (انتخاب" كنتد. بدينترتيب، كزينش گرى، تابع هلف مندى در ارتباطات است؛ و بر خلاف بسيارى از

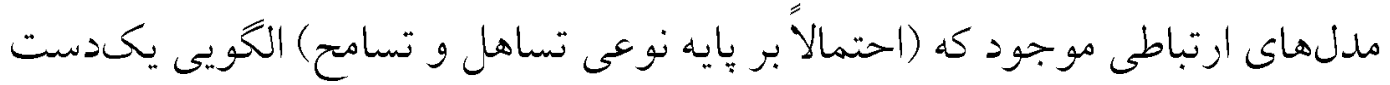

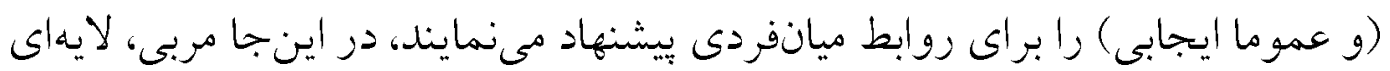

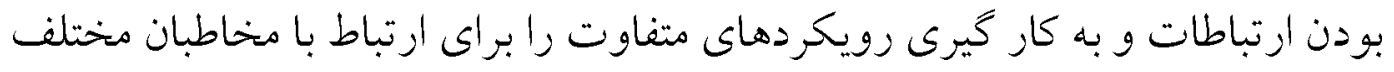
به متربيّان مى آموزد.

\section{هميارى رفاقتى:}

تأثير شبكه حوستان نزديك بر انسان -جهه تأثير ات مثبت و جِه تأثني ات منفى_همواره مورد تأكيد يرورشكاران بوده است. عالامه طباطبايى ضمن توصيدُ اكيد بر سالم بوتنه محيط رفاقتى انسان، مىفرمايند مخالطه با اهل معصيت انسان را با كناه مانوس مىكند

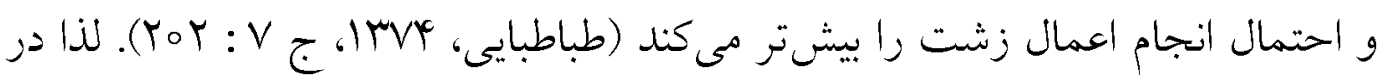

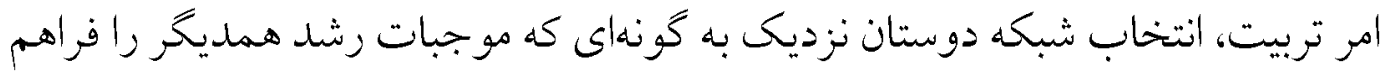
آورند، اصل مهمى است. اين شبكهسازى بايد به صورت آكَاهانه و سنجيده انجام شود. زمانى كه افرادى با اهلاف، ارزشها و علايق مشترك و سازكار، ارتباطات نزديكتر و قوىترى با هم برقرار كننل و نوعى شبكة اجتماعى تشكيل دهند، اين شبكة اجتماعى مرزهايى ايجاد مى كند، از ميزانى از ثبات و يايدارى برخوزيدار است و دز داخل شبكه، افر اد اطلاعانت مرتبط تر زا به صوزت موثرترى جذب و يردازش مي كنتل، خودشان رشد

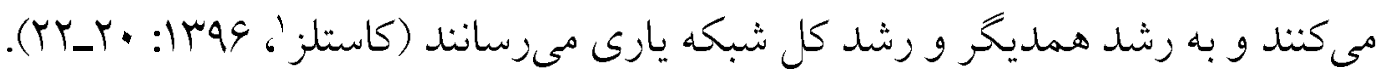
بلدين ترتيب، طراحى آكاهانه و سنجيده شبكه دوستان متربّى، يا كمك به او در اين راستا، مغيد نيز يكى از اصول مهمم تربيت اجتماعى است. 


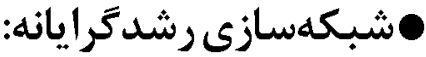

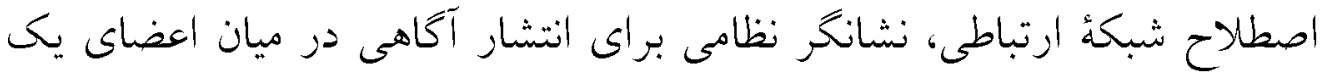

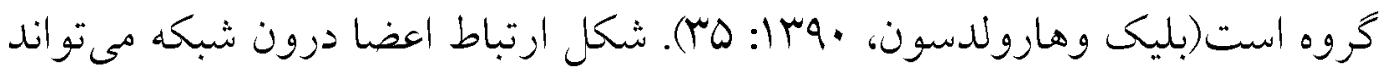

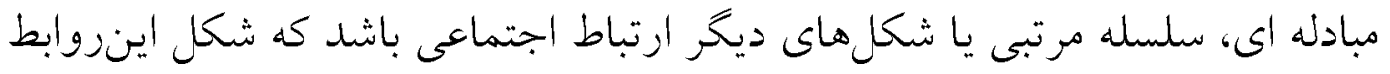

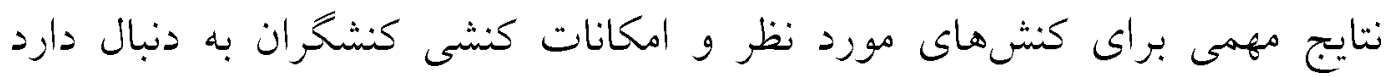

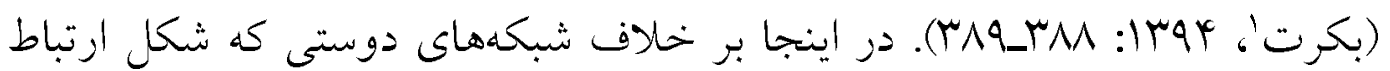

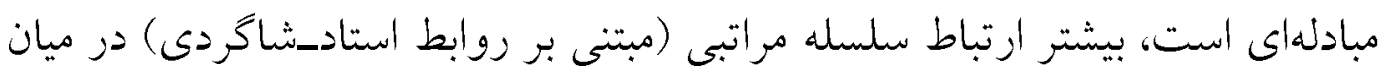

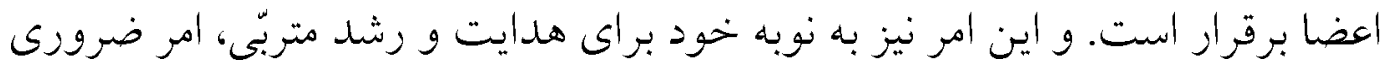

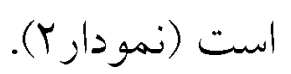

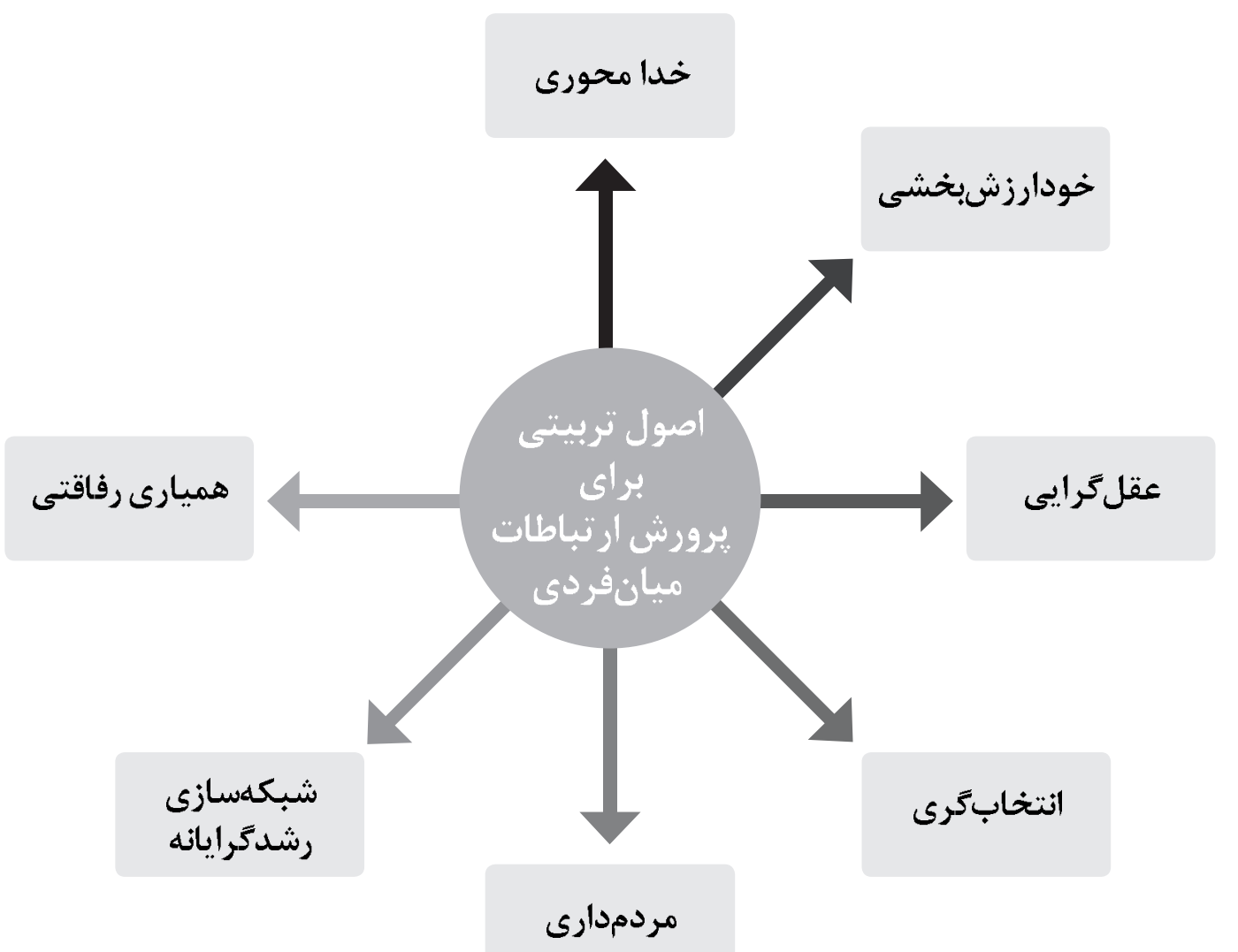

نمودار r. اصول تربيتى ناظر بر برورش ارتباطات ميان فردى 
اصول (ارتباطات ميان فردى)) بر استاس

ديدكاه علامه حلى و استخرائ دلالت هاى تربيتى آن

TrT-149

\section{بحث و نتيجلكيرى}

براى كسانى كه در زمينه تربيت اجتماعى نسل جديد فعاليت مىكنند، يكى سؤال

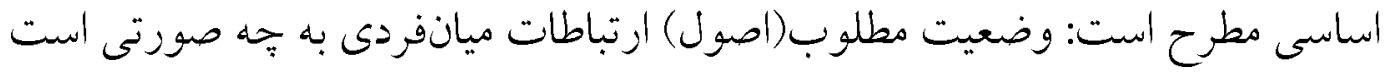

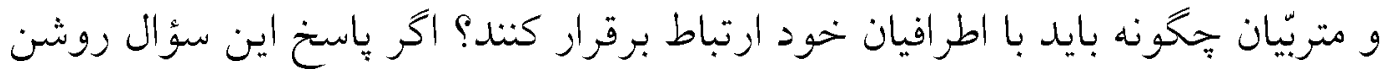

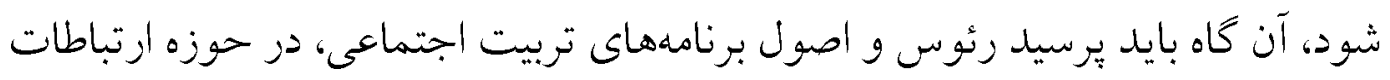

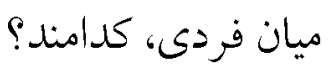
در اين مقاله، ابتدا تلاش شد تا اصول ارتبطات ميانفردى بر اساس حيدكاه علامه

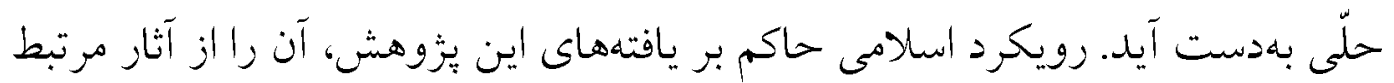

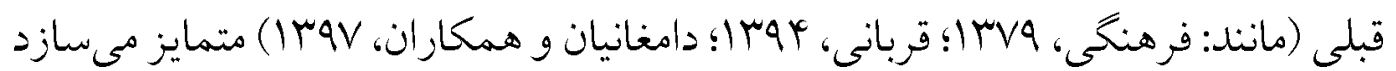

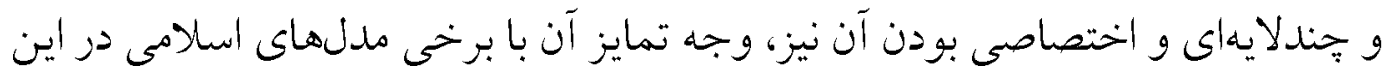

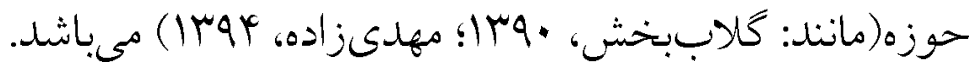

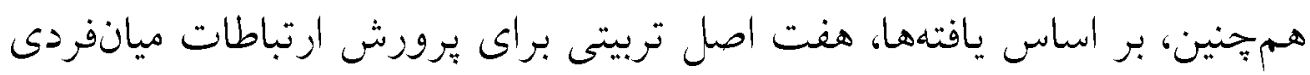

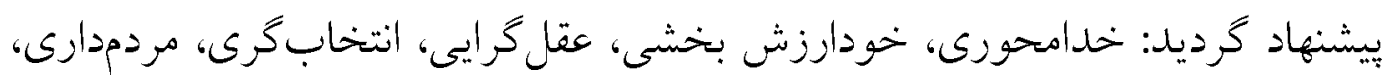
شبكهازى رشدكرايانه و هميارى رفاقتى.

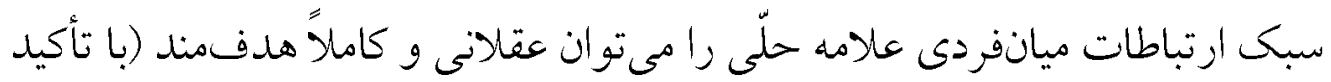

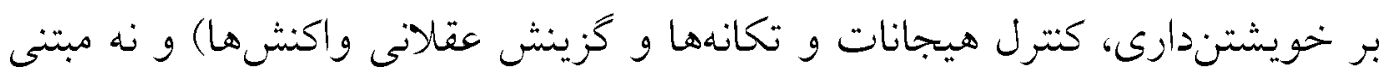

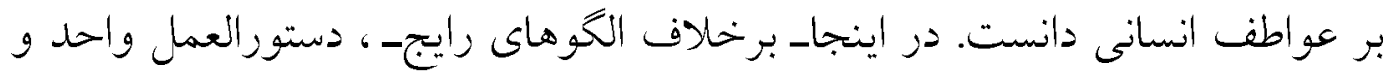

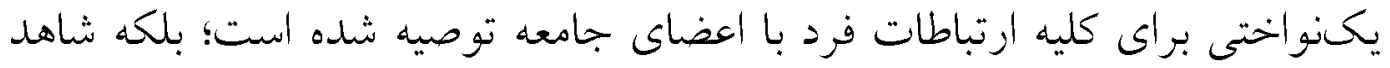

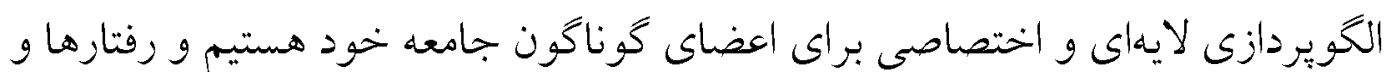

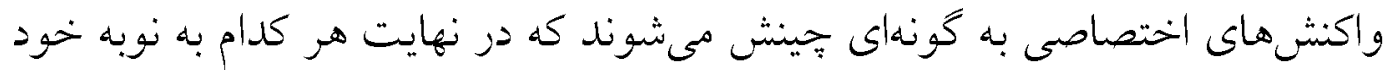

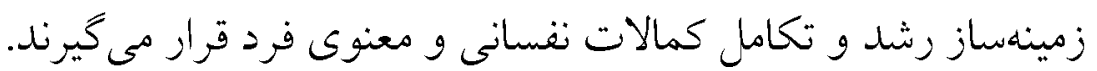

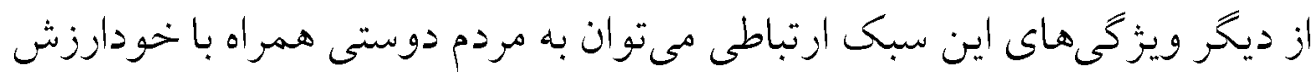

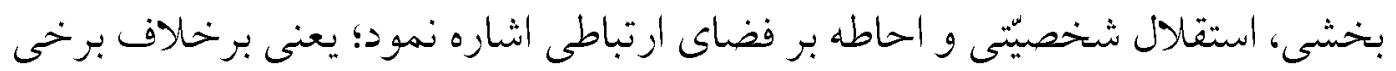

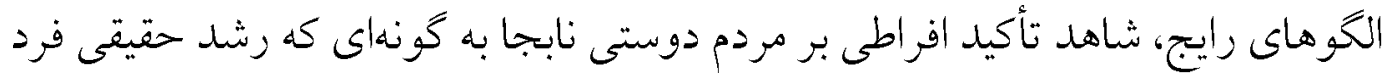

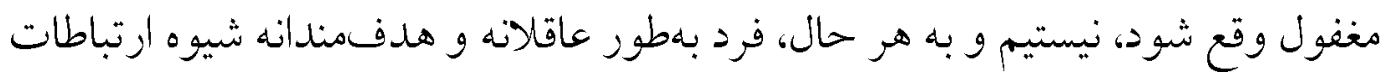

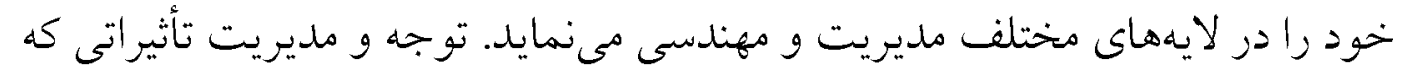

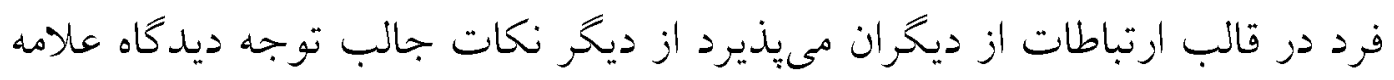


است. بدينمعنا كه آدمى با زويكرد زشدكرايانه خويش بايد مراقبت نمايد تا خود را

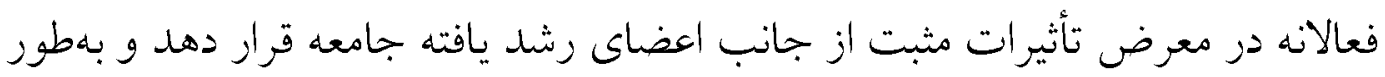

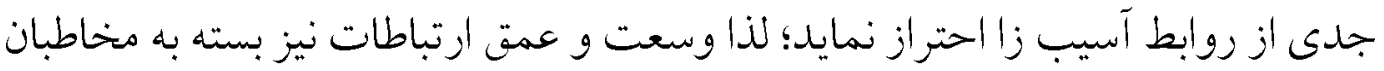

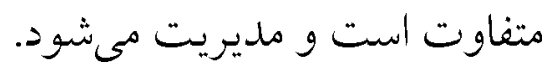

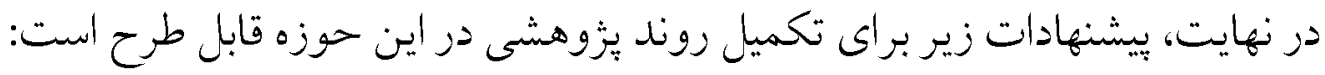

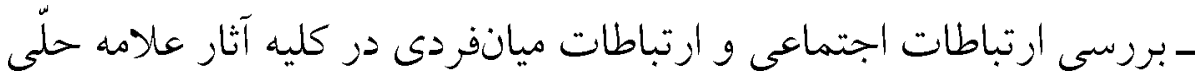

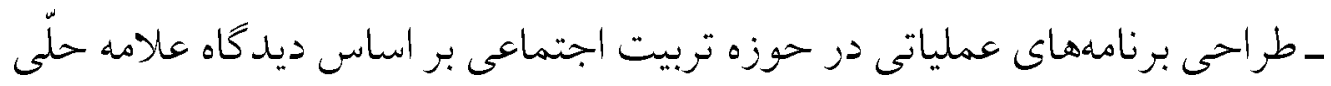

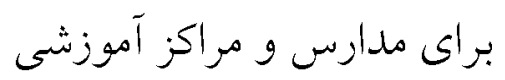

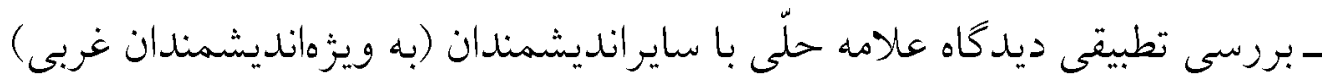
حز اين حوزه

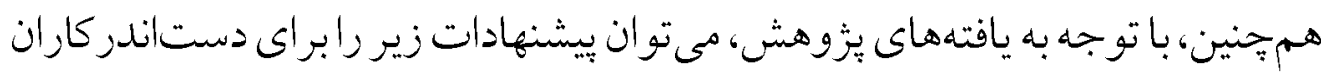
تربيت مطرح نمود:

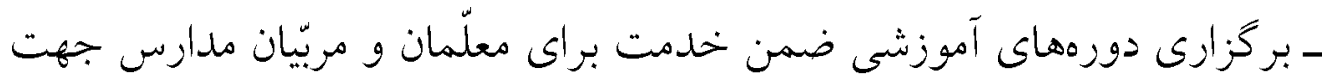

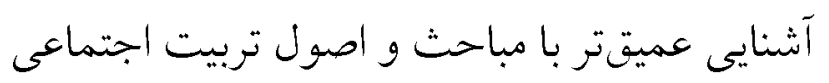

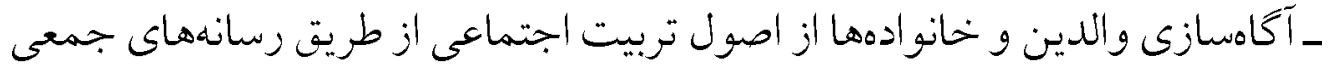

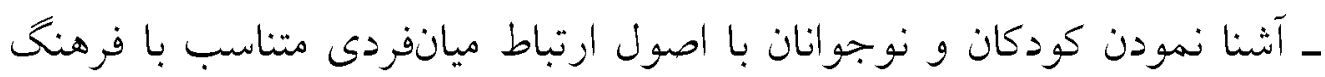

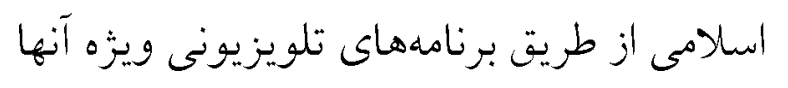

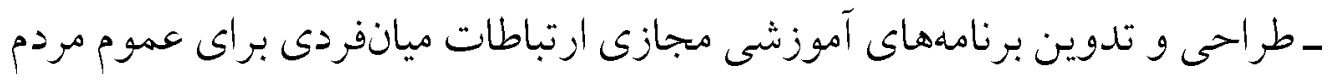
(از طريق شبكههاى اجتماعى مجازى) 


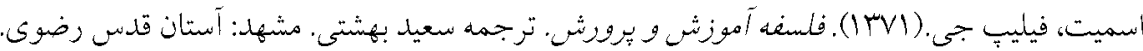

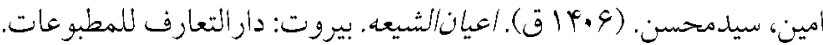

$$
\begin{aligned}
& \text { باقرى، خسرو. (IFAf) :Kاهى دوباره به تربيت السلامى. جلا نوم. تهران: ملرسه. }
\end{aligned}
$$

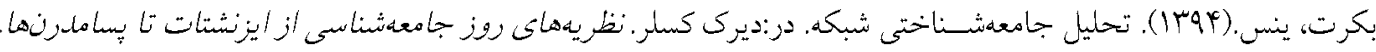

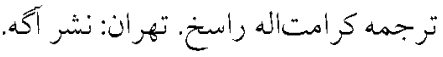

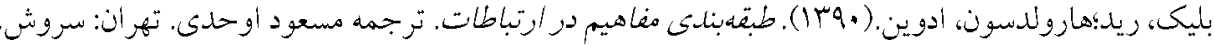

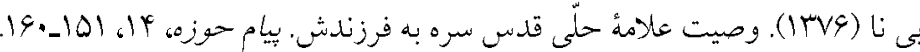

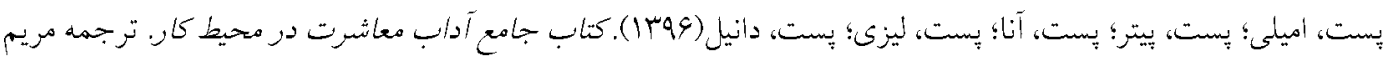
تقديسى. تهر أن: يندأز تابان.

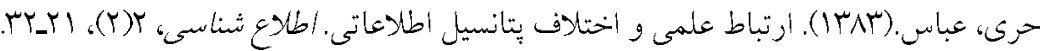

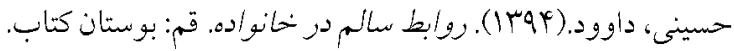

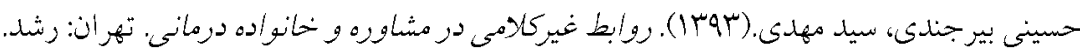

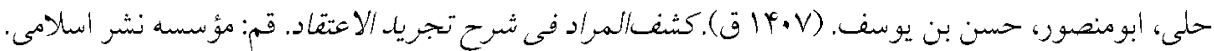

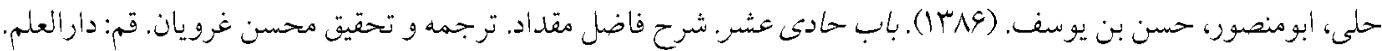

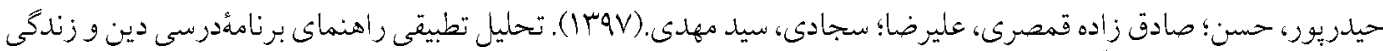

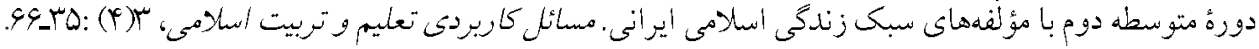

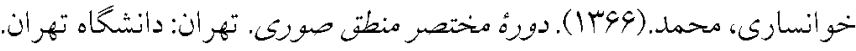

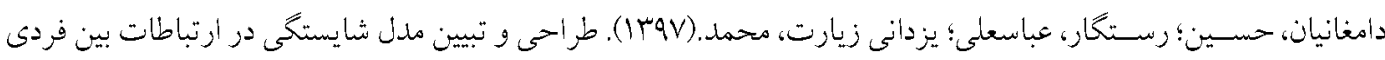

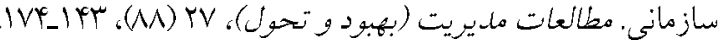

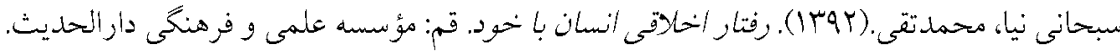

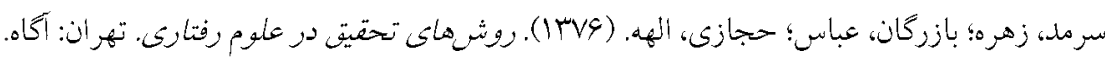

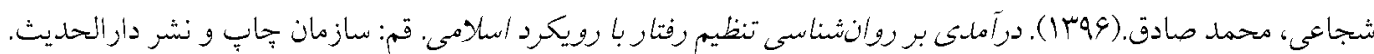

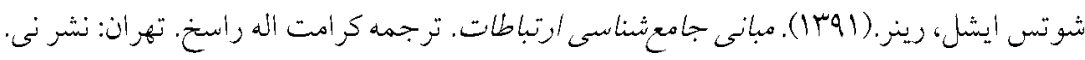

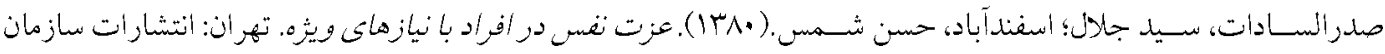

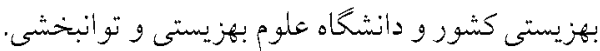

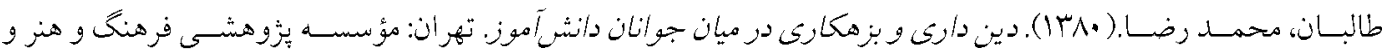
ازنباطات.

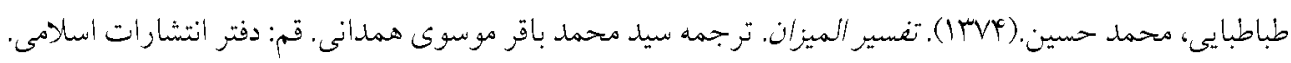

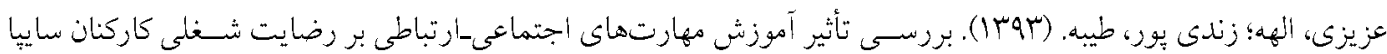

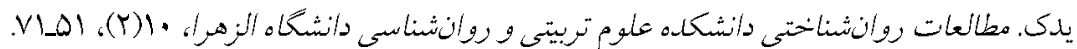

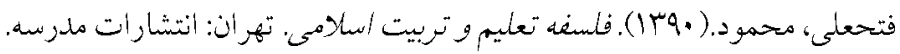
فرامرز قراملكى، احلد) 


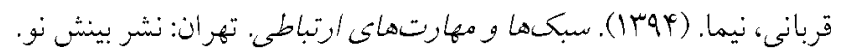

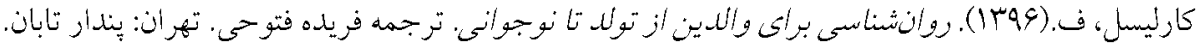

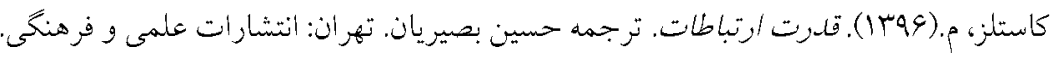

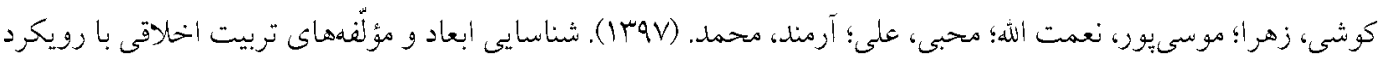

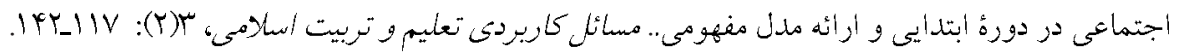

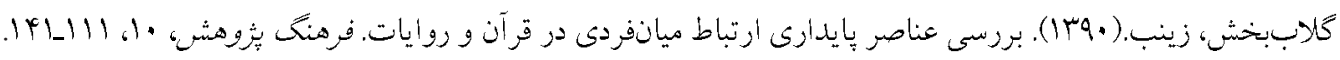

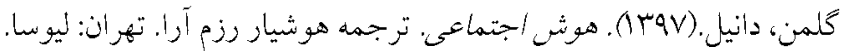

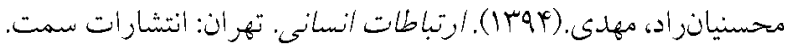

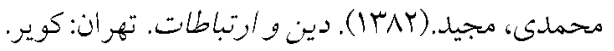

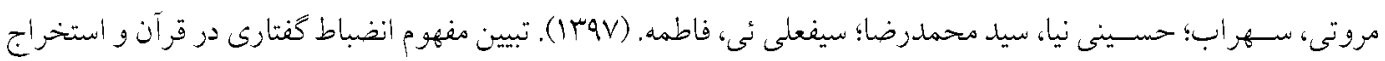

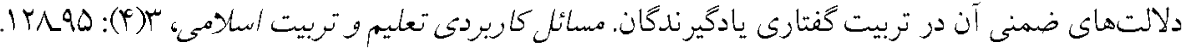

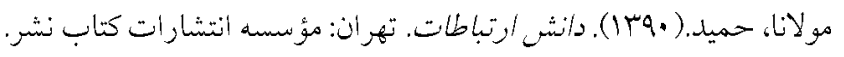

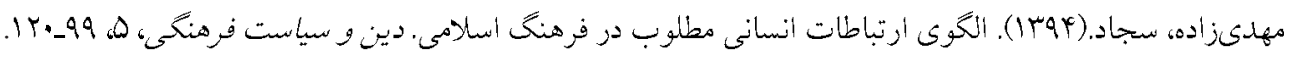

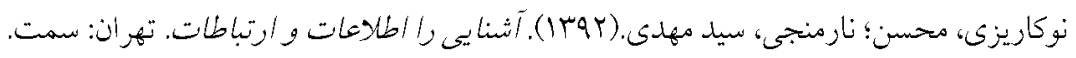

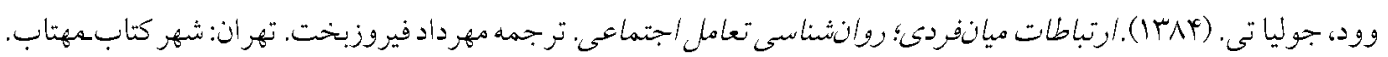

Floyd, K. (2009). Interpersonal communication: The whole story. Boston: McGraw-Hill.

Jennifer, M. A. J., Wefald, K. W., \& Van, I. (2016). Transformational leader attributes: Interpersonal skills, engagement, and well-being. Leadership \& Organization Development Journal, 37(5), 1-30.

Keyton, J., Caputo, J. M., Ford, E. A., Fu, R., Leibowitz, S. A., Liu, T., \& Wu, C. (2013). Investigating verbal workplace communication behaviors. Journal of Business Communication, 50(1), 152-169.

Pipsa, P., \& Tarja, V. (2013). Measuring interpersonal communication competence in SME internationalzation. Journal of Intercultural Communication, 33(1), 1-23.

Robbins, S. P. (2005). Organizational behavior. $11^{\text {th }}$ ed. Prentice Hall India. 